〔95]ポリアクリロニトリルの希薄溶液物性に及ぼす重合条件の影響 (1967 年 3 月 22 日受理)

上出健二*・小林秀彦** $\cdot$ 宮崎幸雄 ${ }^{* *} \cdot$ 中山暢三 ${ }^{* * *}$

要 旨 ポリアクリロニトリル（PAN）の希薄溶液物性に及ぼす試料の重合条件の影響を検討した。 $20^{\circ} \mathrm{C} に お け る \mathrm{~N}, \mathrm{~N}^{\prime}$-ジメチルホルムアミド (DMF) 溶液について, 光散乱, 粘度測定を行なった。レ ドックス, または非レドックス触媒を開始凨として, 水溶液, または有機溶媒中でけん濁, または沈殷 重合した分別物を試料として利用した。さらに，重合温度の効果を調へるために，レドックス低温 $\left(-20^{\circ} \mathrm{C}\right)$ 重合物を用いた。重合条件を変えても重合物の局部的立体規則性度は変わらないことを, あ らかじめ高分解能核磁気共鳴吸収スプクトルよって確かめた。沈殷重合物の DMF 溶液の屈折率の漉 度依存性は他の重合物のそれより大き。PANはかなり大きい見かけの偏光解消度 $\rho_{u, a p}$ をむつ。 $\rho_{u, a p}$ は分子量の增加とともに減少し, 重合条件によっても影響される。特に, 非レドックス系沈股重合物 (ペンゼン溶媒) の $\rho_{u, a p}$ は大きい。螢光を補正した偏光解消度は, 分子量, 重合条件によらず, 0.01 〜 0.02 に減少した。䖝光を補正しないで得られた Zimm プロットの $c \rightarrow 0$ 外插線は, $\theta$ の小さい領域 で負となることがある。螢光を補正すると, ほぼ正常の Zimm プロットが得られた。一般に Huggins 係数 $k_{1}$ は分子量 $\left(\bar{M}_{w}\right)$ の增加につれて增加したが, ペンゼンを溶媒とする非レドックス采沈磦重合 物では, 低分子量側で逆に分子量の增加とともに減少した。

PAN-DMF $\left(20^{\circ} \mathrm{C}\right)$ について, 非レドックス系沈殿重合物 (ペンゼン溶媒) では,

他の重合物では, $[\eta](\mathrm{d} l / \mathrm{g})=4.29 \times 10^{-4} \bar{M}_{w}^{0.71}$

$$
[\eta](\mathrm{d} l / \mathrm{g})=4.66 \times 10^{-4} \bar{M}_{w}^{0.71}
$$

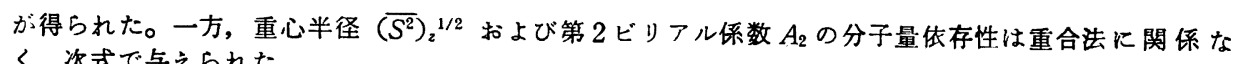
く, 次式で与えられた。

$$
\begin{aligned}
& \left(\bar{S}^{2}\right)_{z}^{1 / 2}(\mathrm{~cm})=1.27 \times 10^{-9} \bar{M}_{w}{ }^{0.62} \\
& A_{2}\left(\mathrm{ml} / \mathrm{g}^{2}\right)=4.94 \times 10^{-2} \bar{M}_{w}{ }^{-0.27}
\end{aligned}
$$

上述の各式の係数は互いに理論的関係を渾足した。

Stockmayer-Fixman プロットの適用性を榆討した。プロットの直線部分の $\bar{M}_{w}^{1 / 2} \rightarrow 0$ への外捙から Flory 定数 $K$ を求め, ベンゼン中沈段重合物に対して, $3.1 \times 10^{-3}$, 他の重合物に対しては $3.6 \times 10^{-3}$ を得た。 $A_{2}$ を 0 にする混合溶媒（エチレンカーボーネート水溶液， $44^{\circ} \mathrm{C}$ ）中で粘度測定を行ない, 後 者の重合物に対して $K_{a p}=3.5 \times 10^{-3}$ を評価した。 $K$ 以外の溶液パラメータを決定して，粘度式たけ が重合条件の影響を受けることを溶液理論より説明した。螢光は異種棈造としてのアミド,カルボン酸, カルボン酸エステルなどの含有量には関係ない。レドックス重合物の螢光はイオン型で, 触媒残基が原 因であるのに対し，ベンゼン中非レドックス重合物の螢光は非イオン型で，拈そらくはベンゼン環を含 む構造がその原因であると推論した。ベンゼン中非レドックス重合物の溶液物性が特異的であるのは, 分岐構造の存在や立体規則性度の変化からは説明できなくて, むしろ螢光檏造と密接な関係がある。

\section{1. 緒言}

近年, 重合条件を変えると, 得られる重合物分子の立 体規則性度がかなり広範囲に変化することが, ポリ酢酸 ビニル, ポリ塩化ビニル, ポリアクリル酸メチル, ポリ ビニルェーテル, ポリスチレン, ポリプロピレンなど多 数の高分子物質について明らかにされた。また, 分子の 立体規則性度とその溶液物性との関連性についても多く

*旭化成工業株式会社繖維研究所（大阪府高槻市八丁 啜町)

** 旭化成工業株式会社技術研究所（東京都板橋区志村 中台町)

*** 旭化成工業株式会社䋐維企画部（大阪市北区堂島）
の研究がある。

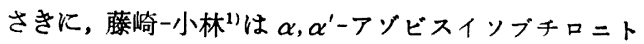
リルを触媒として水けん濁重合法で得られたポリアクリ ロニトリル (以下 PAN と略記) の $\mathrm{N}, \mathrm{N}^{\prime}$-ジメチルホ ルムアミド (以下 DMF と略記) 溶夜の固有粘度が, 過 硫酸アンモニウム-酸性覀硫酸ナトリウム系のレドック ス触媒を開始剤として水けん濁重合法で得られた分別区 分に比べて，同一分子量でより小さいことを実験的に認 め、ポリアクリロニトリルの希薄溶液物性がその重合法 によってかなり大きく影響される可能性があることを指

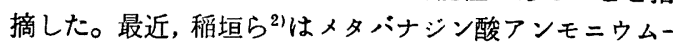
亜硫酸ナトリウム系のレドックス重合物のシメチルホル ムアミド溶液の固有粘度と超遠心法による分子量を測定 
し, Stockmayer-Fixman プロッドから分子鎖の con formatian (配位) を評価した。彼らによると, unperturbed dimension（理想溶液中の広がり）に関しては $60^{\circ} \mathrm{C}$ 重合物が $-30^{\circ} \mathrm{C}$ 重合物よりも小さく，これより重 合温度を下げるにつれて分子鎖中のシンジオタクチック 成分が增加すると推論された。ポリアクリロニトリルの ミクロタクチシテ （局部的立体規則性度）が重合方法 によってどの程度変化しらるかについては, 村野一山 寺4, 松崎ら ${ }^{5)}$ が磁気共鳴法を利用して検討している。 彼らの結果によると,ラシシカル重合物では重合条件を大 きく変えても，その立体規則性度はほとんど変化しな W。

稲垣らの推論2'は立体規則性度についての知見" と矛 盾するようにみえるし，藤崎一小林" ${ }^{1}$ の実験結果も立体 規則性度の変化から説明できるかどらか現状では確かで はない。
本論文では，まず重合条件をかえて重合されたボリア クリロニトリルの立体規則性度について高分解能核磁気 共鳴吸収拈よび赤外吸収スベクトル測定から検討した。 次いで，希薄溶液の粘度打よび光散乱測定を行ない，重 合条件（できるならば分子の微細構造）と希薄溶液物性 との間の関連性を詳細に調へた。

\section{2. 実 験}

\section{1 重 合}

Table 1 とまとめてある重合条件を利用してアクリ ロニトリルをラジカル重合した。原料アクリロニトリル は常法に従って精製した。重合は酸素ガスが十分除去さ れた窒素ふんい気下で行なった。触媒として非レドック ス系またはレドックス系を用い，水けん濁重合法または 沈殿重合法を利用した。レドックス重合における重合温 度の効果を調べるために低温 $\left(-20^{\circ} \mathrm{C}\right)$ 重合を試みた。

Table 1. Polymerization conditions of polyacylonitrile.

(A) Suspension polymerization in aqueous solvent with non-redox catalyst (S- $n \mathrm{R}$ )

\begin{tabular}{c|c|c|c|c|c|c|c|c|c}
\hline Sample No. & ANa) $^{(\mathrm{g})}$ & $\begin{array}{c}\text { AIBNb) } \\
(\mathrm{g})\end{array}$ & $\begin{array}{c}\beta-\mathrm{SH}^{\mathrm{e})} \\
(\mathrm{g})\end{array}$ & $\begin{array}{c}\mathrm{PVA}^{\mathrm{d})} \\
(\mathrm{g})\end{array}$ & $\begin{array}{c}\text { Water } \\
(\mathrm{g})\end{array}$ & $\mathrm{pH}$ & $\begin{array}{c}\text { Temp. } \\
\left({ }^{\circ} \mathrm{C}\right)\end{array}$ & $\begin{array}{c}\text { Time } \\
(\mathrm{hr})\end{array}$ & {$\left[\mathrm{[}^{\mathrm{e})}\right.$} \\
\hline Q-P AN & 100 & 0.20 & 0.17 & 0.4 & 300 & 2.1 & 60 & 4 & 3.4 \\
\hline
\end{tabular}

(B) Precipitation polymerization in organic solvent with non-redox catalyst (P-nR (B))

\begin{tabular}{c|c|c|c|c|c|c}
\hline \hline Sample No. & ANa) $^{(\mathrm{g})}$ & $\operatorname{AIBN}^{\mathrm{b}}(\mathrm{g})$ & Benzene $(\mathrm{g})$ & Temp. $\left({ }^{\circ} \mathrm{C}\right)$ & Time $(\mathrm{hr})$ & {$[\eta]^{\mathrm{e})}$} \\
\hline $\mathrm{S}-17$ & 100 & 0.20 & 400 & 50 & 14 & 5.38 \\
\hline
\end{tabular}

(C) Precipitation polymerization in organic solvent with non-redox catalyst $(\mathrm{P}-n \mathrm{R}(\mathrm{H}))$

\begin{tabular}{c|c|c|c|c|c|c}
\hline \hline Sample No. & ANal $^{(\mathrm{g})}$ & $\operatorname{AIBN}^{\mathrm{b}}(\mathrm{g})$ & $n$-Heptane $(\mathrm{g})$ & Temp. $\left({ }^{\circ} \mathrm{C}\right)$ & Time $(\mathrm{hr})$ & {$[\eta]^{\mathrm{e} /}$} \\
\hline SHA-1 & 300 & 0.3 & 1200 & 50 & 25 & 5.97 \\
\hline
\end{tabular}

(D) Suspension polymerization in aqueous solvent with redox catalyst (S-R (40))

\begin{tabular}{c|c|c|c|c|c|c|c}
\hline \hline Sample No. & ANo) $^{(\mathrm{g})}$ & APS $^{\prime}(\mathrm{g})$ & $\mathrm{SBS}^{\mathrm{g})}(\mathrm{g})$ & Water $(\mathrm{g})$ & Temp. $\left({ }^{\circ} \mathrm{C}\right)$ & Time $(\mathrm{hr})$ & {$[\eta]^{\text {e) }}$} \\
\hline ST-M-1 & 100 & 0.8 & 0.3 & 1600 & 40 & 2.5 & 4.53 \\
\hline
\end{tabular}

(E) Suspension polymerization in aqueous solvent with redox catalyst $(S-R(-20))$

\begin{tabular}{c|c|c|c|c|c|c|c|c|c}
\hline \hline $\begin{array}{c}\text { Sample } \\
\text { No. }\end{array}$ & $\begin{array}{c}\text { ANa) } \\
(\mathrm{g})\end{array}$ & $\begin{array}{c}\text { SBSg) } \\
(\mathrm{g})\end{array}$ & $\begin{array}{c}\text { Sulfuric acid } \\
(\mathrm{g})\end{array}$ & $\begin{array}{c}\text { Ethanol } \\
(\mathrm{g})\end{array}$ & $\begin{array}{c}\text { Water } \\
(\mathrm{g})\end{array}$ & $\begin{array}{c}\text { Catalyst } \\
(\mathrm{g})\end{array}$ & $\begin{array}{c}\text { Temp. } \\
\left({ }^{\circ} \mathrm{C}\right)\end{array}$ & $\begin{array}{c}\text { Time } \\
(\mathrm{hr})\end{array}$ & {$\left[^{[\eta]^{\mathrm{e}}}\right.$} \\
\hline SS-492 & 100 & 3.7 & 1.44 & 246 & 492 & 74.5 & -20 & 8 & 3.4 \\
\hline
\end{tabular}

a) Acrylonitrile, b) Azo bisisobutylnitrile, c) $\beta$-Mercatoethanol, d) Polyvinyl alcohol,

e) Intrinsic viscosity in $\mathrm{N}, \mathrm{N}^{\prime}$-dimethylformamide at $35^{\circ} \mathrm{C}$, f) Ammonium persulfate,

g) Sodium bisulfite, h) Catalyst prepared from cobalt acetate and acetic anhydride 


\section{2 分 別}

2.1 で得られた未分別物を $\mathrm{N}, \mathrm{N}^{\prime}$-シメチルスルホキ サイト (DMSO)ートルェン系分別沈殿法によって $35^{\circ} \mathrm{C}$ に执いて分別した。分別法の詳細は藤崎一小林の方法”に 従った。

\section{3 分別物のキャラクタリゼーション}

\subsection{1 高分解能核磁気共鳴 (NMR) スペクトル} 分別物の立体規則性度を調べるため, 村野一山寺の 方 法年に準じて $120^{\circ} \mathrm{C}$, NaCNS- $\mathrm{D}_{2} \mathrm{O}$ (50:50，重量比） 溶液の高分解能 NMR スペクトル (Varian A-60型 NMR スペクトロメーター）を測定した。スペクトルを 解析して立体規則性度を定量しなかったが，スペクトル の形, 特にメチレン基プロトンの化学シフトは重合物の 重合方法によってほとんど変化しなかった。したがっ て Table 1 に示した程度の重合条件の違い(いずれも ラジカル重合である) は, 重合物の局部的な立体規則性 度（ミクロタクチシティ）をかえない*1。これは 1 ，で も述べたよらに，村野一山寺の結果 (原報4), Table 2 参照) ともよく一致する。

\section{3 .2 赤外吸収 (IR) スペクトル}

分別物のシメチルスルホキサイド溶液からフィルムを 調製し，その IR スペクトルを日立回折格子赤外分光光 度 125 形を用いて測定した。Table 1 にのせてある重合 物はすべて基本的には同一のスペクトル特性を示した。 詳細に IR スペクトルを調べると, PAN の供種構造*2に 原因すると思われる吸収バンドが $1625 \mathrm{~cm}^{-1}, 1680 \mathrm{~cm}^{-1}$ および $1720 \mathrm{~cm}^{-1}$ に認められた。アクリロニトリルとア クリル酸アミドの共重合体の赤外吸収バンドと比較する ことによって, $1625 \mathrm{~cm}^{-1}$ と $1680 \mathrm{~cm}^{-1}$ の吸収はそれぞ れアミド $\left(\mathrm{CONH}_{2}\right)$ 基の $\mathrm{NH}$ 変角振動および $\mathrm{CO}$ 伸縮振 動に㷌属される。また, アクリロニトリルとアクリル酸 の共重合体拉よびアリロニトリルとアクリル酸エステ ルの共重合体の赤外吸収バンドと比較することによっ て, $1720 \mathrm{~cm}^{-1}$ の吸收はカルボン酸（COOH）ぬたはカ ルボン酸ェステル ( $\left.\mathrm{RCOOR} \mathrm{R}^{\prime}\right)\left(\mathrm{R}, \mathrm{R}^{\prime}\right.$ は炭化水素基) のCO伸縮振動に㷌属される。この結果, PANの分子 鎖はアミド基とカルボン酸基, またはカルボン酸エステ ル基を異種榑造としてもつことが確かめられた。これら の異種構造の含有量が重合体の重合条件によってどのよ らに变化するかを調べた（Fig. 1)。Fig. 1 では, 異種 搆造の含有量の目安としてハシンド $1720 \mathrm{~cm}^{-1}$ の吸光度を

※1ベンゼンを溶媒とした沈䟝重合物のみ，他の重合物 とメチン基プロトンの吸収スペクトルの山の形にお いて相違した。前者は吸収スペクトルの山の分離が 不明りょらであった。これが分子構造の規則性に関 係するかどらか，まだわからない。

*2 本論文では, $\left(\mathrm{CH}_{2} \mathrm{CHCN}\right)_{n}$ 以外の柾造を異程棈造と 定義した。

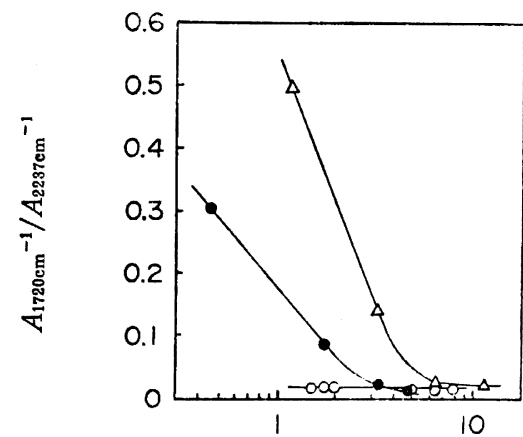

$[\eta] 35^{\circ} \mathrm{C}(100 \mathrm{ml} / \mathrm{g})$

O: P- $n \mathrm{R}(\mathrm{B}), \quad$ : S-R(40), $\Delta: \mathrm{S}-n \mathrm{R}$. Carbonyl group in PAN which can be assigned to band at $1720 \mathrm{~cm}^{-1}$ decreases with molecular weight. There are no correlationships between the carbonyl content and the intensity of fluorescence and characteristic behabior of P- $n \mathrm{R}$ (B) fractions in $\mathrm{DMF}$ at $20^{\circ} \mathrm{C}$ can not be interpreted in terms of the carbonyl or acid amide group contents.

Fig. 1. Plots of ratio of absorbance of band at $1720 \mathrm{~cm}^{-1}$ to that at $2237 \mathrm{~cm}^{-1}$ (nitrile group as internal thickness band) $A_{1720}$ $\mathrm{cm}^{-1} / A_{2237} \mathrm{~cm}^{-1}$ against molecular weight.

とってある。低分子量物ほど $\mathrm{CO}$ 基が増加する。 $\mathrm{CO}$ 基 の含有量は

非レドックス水中けん濁重合物>レドックス水中けん 濁重合物>ベンゼン中非レドックス沈殿重合物 の順に減少する。なお，他の異種構造（たとえば, シア ノェチル化，またはケテンイミン形成に際して生ずる異 種構造)は赤外吸収スペクトルからは検出できなかった。 ただし、レドックス重合物の IR スペクトルは，C-C 伸 縮振動, または $\mathrm{CH}_{2}$ 横ゆれ振動に原因する $1063 \mathrm{~cm}^{-1}$ の強い吸収バンド付近 $\left(1030 \mathrm{~cm}^{-1}\right)$ に弱い肩をもつ。 これには触媒残基としてのスルホン基 $\left(\mathrm{SO}_{3} \mathrm{Na}\right)$ が関倸 しているようである。異種構造としてのアミド基。カル ボン酸基またはカルボン酸エステル基は, 重合過程にお ける $\mathrm{CN}$ 基のおたたやかな加水分解 $\left(\mathrm{CONH}_{2}\right.$ 基) または激 しい加水分解（COOH または $\mathrm{RCOOR}^{\prime}$ 基）によって生 成したのであろう。稲垣ら゙によると, メタバナジン酸 アンモニウムと亜硫酸ナトリウムからなるレドックス触 媒を用いて低温 $\left(-30^{\circ} \mathrm{C}\right)$ で重合させた重合物は， ： ンド $950 \mathrm{~cm}^{-1}$ に吸収をもつ。Table 1 の方法で重合し た低温レドックス重合物の IR スペクトルには $950 \mathrm{~cm}^{-1}$ の吸収は存在しない。

\section{4 光散乱}

2.4.1 届折率の濃度変化

屈折率の濃度変化 $(\partial n / \partial c)$ を島津製作所製 Debye 


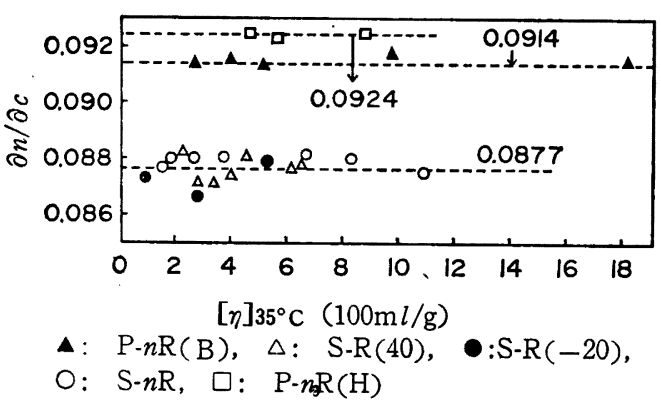

The refractive increment $\partial n / \partial c$ in dimethylformamide at $436 \mathrm{~m}_{\mu}$ has been given as 0.0877 , 0.0914 and 0.0924 , respectively, corresponding to the polymerization conditions. $\partial n / \partial c=0.087$ is in good agreement with those in literatures.

Fig. 2. Plots of refractive increment $\partial n / \partial c$ with incident beam of $436 \mathrm{~m}_{\mu}$ against intrinsic viscosity in $\mathrm{N}, \mathrm{N}^{\prime}$-dimethylformamide (DMF) at $35^{\circ} \mathrm{C}$.

型示羑屈折率計によって, $20^{\circ} \mathrm{C} て ゙$ 測定した。

重合条件を変えて重合した重合物の $\partial n / \partial c$ を Fig. 2 に示す。同じ条件で重合された重合物の $\partial n / \partial c$ は分 子量に関倸なく，ほぼ一定値を与える。すなわち，有機 溶媒中の沈股重合物は $\partial n / \partial c=0.0914$ (ペンゼン), 0.0924 ( $n$-ヘプタン), 他のラジカル重合物の $\partial n / \partial c$ は 0.0876 である。後者の值は Krigbaum-Kotliar ${ }^{81}$ の測 定值 (0.089) よりやや小さく, Cleland-Stockmayer") の值 (0.083) よりもかなり大きい。沈段重合物の $\partial n$ / $\partial c$ は明らかに懸濁重合物のそれよりも大きい。すでに 藤崎阬が指摘したように, $\partial n / \partial c$ を大きくする誤差要因 として, 使用するジメチルホルムフミドが測定前に吸湿 していることがあり， $\partial n / \partial c$ を小さくする要因には，屈 折率测定途中の吸湿は装置 (Debye 型) の形状から溶 媒槽の方が起こりやすいこと, 重合体の吸湿, 溶夜を七 ルに移しかえる時間が溶媒の処理時間よりも王倒的に長 いための溶液の吸湿など,がある。だから， $\partial n / \partial c$ の値 の大小は測定の信頼性の目安を与えるものではない。本 論文では,すべての試料の $\partial n / \partial c$ を全く同一の実験方 法で測定しているから， $\partial n / \partial c$ の差は決して測定 過 程 における吸湿に原因しない。重合方法による高分子鎖の 微細構造 (末端基, 分岐, 異種結合, 立体規則性度な ぞ）の変化か～$\partial n / \partial c$ の変化に対応している。

\section{4 .2 螢光を考虑した光散乱測定}

光散乱実験は島津光電式光散乱光度計 PG-21 型を利 用して, $20^{\circ} \mathrm{C}$ で行なった。溶液の精製は藤崎日) の報告 に準じ。

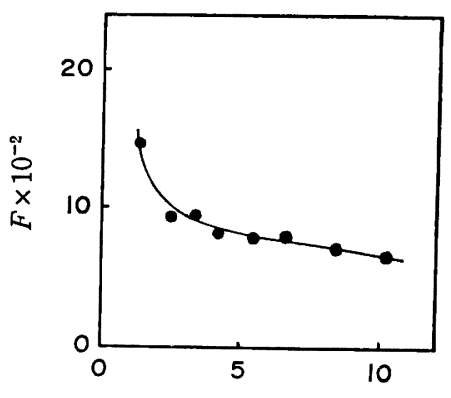

$[\eta] 35^{\circ} \mathrm{C}(100 \mathrm{~m} l / \mathrm{g})$

Polymer concentration: $0.25(\mathrm{~g} / 100 \mathrm{ml})$, solvent: DMF.

$F$ is the relative intensity of fluorescence defined by the ratio of the intensity of solution to the fluoresce intensity of quinine sulfate (concetration: $0.0011 \mathrm{~g} / 100 \mathrm{ml}$ ) at 455 $\mathrm{m}_{\mu}$ with incident light of $365 \mathrm{~m}_{\mu}$

Fig. 3. Relative fluorescence intensity $F$ of polyacrylonitrile $(S-R(40)$ ) fractions at $410 \mathrm{~m}_{\mu}$ with incident light of $365 \mathrm{~m}_{\mu}$ plotted against intrinsic viscosity in DMF at $35^{\circ} \mathrm{C}$.

PAN の DMF 溶液が室温で螢光を発することは，す でに多数の研究者によって報告されている。たとえば， Cleland-Stockmayer' (1955) は, $\alpha, \alpha^{\prime}$-フソビスイン ブチロニトリルを開始剤とし, サクシノニトリル(溶媒) 中で重合させた PAN の DMSO 溶液 $\left(25^{\circ} \mathrm{C}\right)$ が, 光散 乱測定の際, 水銀の $546 \mathrm{~m} \mu$ の入射光より長波長（赤 色)側に螢光を発することを認め, Brice $5^{101}$ の偏光解消 法を利用して分子量を決定した。彼らによると，Zimm プロットの濃度 0 の外插線は螢光補正の影響をあまり受 けないが, 散乱角 $(\theta)=0$ のプロットの濃度依存性は溃 光に大きく影響される。Krigbaum-Kotliar ${ }^{8}$ (1958) は 水銀灯と溶液セルの間に黄色フィルターを, また, 溶液 セルと光電管の間に青色フィルターを插入して螢光を減 少させた。藤崎日)（1961）は過硫酸フンモニウムー過硫酸 カリー酸性硫酸ナトリウム系を開始剤としたレドックス （水けん濁）重合物（Table 1 のS-R(40)に相当する) のDMF 溶液の螢光を系統的に調べた。 $365 \mathrm{~m} \mu$ の入射光 を照射すると, $410 \mathrm{~m} \mu$ にピークをもつ非常に強い螢光 が発生する。しかし， $546 \mathrm{~m} \mu$ の光を照射してもほとん ど螢光は認められなかった。

螢光強度は，入射光の波長たけではなく試料の分子量 によっても変化する。一般に分子量が小さくなると, 螢 光は大きくなる。このことはすで藤崎到によって明ら かにされた。Fig. 3 に, $365 \mathrm{~m} \mu$ の光を照射したときに 発生する螢光の相対強度 $F$ と PAN 試料 (分別物) の固 
有粘度 $[\eta]$ との関係を示す。ここで， $F$ は $410 \mathrm{~m} \mu$ で観 測された螢光強度の相対値であって, 基準として, 硫酸 キニーネの $0.1 \mathrm{~N}$ 硫酸溶液（濃度 $0.0011 \mathrm{~g} / 100 \mathrm{ml}$ ) に $365 \mathrm{~m} \mu$ の光を照射して得られる螢光の最大強度 (455 $\mathrm{m} \mu$ における強度)を 100 とした ${ }^{61}$ 。この場合, 容器の 中心部にある溶液から発生した螢光が, 螢光発生場所か ら容器表面に到達するまでに吸収される量の補正, 短波 長側が吸収と重なるための補正や光電管の分光感度特性 についての補正など"11は一切行なっていない。Fig 3 か ら明らかなように, 分子量が低くなると, 螢光は無視で きない。

著者らは，予備実験において，有機溶媒中の非レドッ クス采沈殿重合物（Table $1, \mathrm{P}-n \mathrm{R}(\mathrm{B})$ ) の比較的低 分子量区分の光散乱測定 (入射光, $546 \mathrm{~m} \mu$ )を行なっ たところ, $K c\left(1+\cos ^{2} \theta\right) / \Delta R_{U}{ }^{u}(\theta)$ 刘 $\sin ^{2}(\theta / 2)$ 曲線 の勾配が散乱角 $\theta$ の小さい領域に打いて負となった (Fig. 4)。ここで, $K=\left(2 \pi^{2} / \lambda^{4} N_{A}\right) n_{0}{ }^{2}(\partial n / \partial c)$, גは入 射光の波長, $N_{A}$ はアボガド口数, $n_{0}$ は純溶媒の屈折率, $\Delta R_{U}{ }^{u}(\theta)=\Delta I(\theta) r^{2} / I_{0} V$ は入射光, 散乱光ともに自然光 の場合の還元散乱強度, $I_{0}$ は入射光强度 $\Delta I(\theta)$ は $\theta$ 方 向の溶質に原因する散乱光強度, $V$ は散乱体積, $r$ は散 乱場所と観測地点との間の距離である。Fig. 3 に示し たような傾向は，すで高分子電解質の水溶液 ${ }^{21}$ やイン タクチックポリスチレンのモノクロルベンゼン溶液 ${ }^{131}$ ぞについても知られている。後者について, 内山 ${ }^{131}$ は分 子鎖のセグメントの光学的異方性の影響であると説明し た。まず，ポリアクリロニトリルの DMF 溶液の Z imm プロットの $\lim _{c \rightarrow 0}\left(K c\left(1+\cos ^{2} \theta\right) / \Delta R_{U}{ }^{u}(\theta)\right)$ 対 $\sin ^{2}(\theta / 2)$ 曲線の勾配が， $\theta$ の小さい領域では負となるのか，螢光 の混在または光学的異方性のどちらに原因するのか，む し, 両者に原因するならば，その程度の差があるかどう かを娭討した。

入射光として $436 \mathrm{~m} \mu$ を利用すると，Fig. 4 の異常 現象がさらに強調される (Fig. 5)。このことから， Zimm プロットの異常と螢光との関連性が定性的に予想 される。一般に, 螢光を発する高分子溶液の光散乱を測 定する場台, 散乱光を䖝光から分離して測定する必要が ある。Fig. 4，5 で引用したと同一の試料溶液の見かけ の散乱光の強度の波長分布を調へてみると（Fig. 6), 定性的な予想どおり螢光成分が無視できない。しかも， 436 $\mathrm{m} \mu$ または $546 \mathrm{~m} \mu$ を照射した際に発生する螢光の波 長は, 散乱光波長 (したがって, 入射光波長) 飞非常に 接近しているため, sharply cut off フィルター（ある 波長を境にして透過倸数が鋭く変化するフィルター)を

*3 見かけの散乱光の波長分布の測定は, この目的のた めに特別に試作した。装置を利用した光電式光散乱光 度をそのまま用いたのではない。

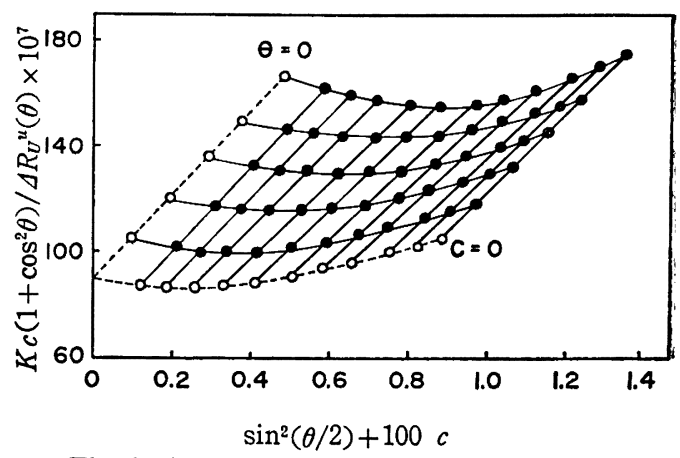

The incident beam: $546 \mathrm{~m}_{\mu}$

The distorted Zimm plot is obtained for the precipitation polymers $(\mathrm{P}-n \mathrm{R})$. The $c=0$ line gives the downward curvature, however, the slope of constant angle lines is constant and almost same as that of the $\theta=0$ line. From preliminary studies, it is confirmed that this kind of distortion can not be causing to the presence of dust or aggregates or the polydispersity of samples.

Fig. 4. Zimm plot for fraction (110-4) $\left(\bar{M}_{w}=\right.$ 1. $2 \times 10^{5},[\eta]_{20}{ }^{\circ} \mathrm{C}=1.91$ ) which is obtained by the heterogeneous free radical polymerization in the presence of benzene.

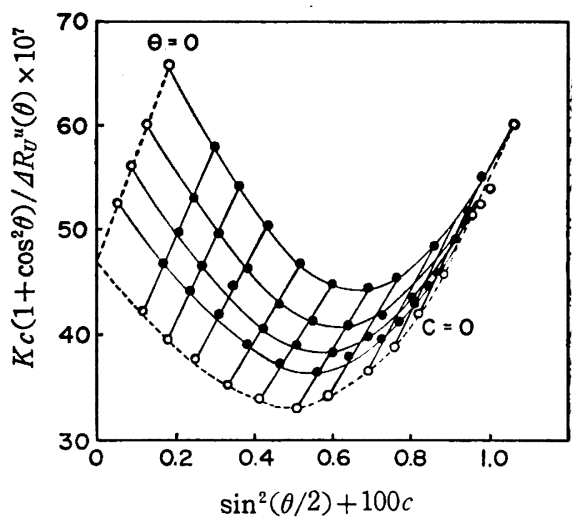

The incident beam: $436 \mathrm{~m}_{\mu}$

The distortion of the $\mathrm{Zimm}$ plot becomes more pronounced if the contamination of fluorescence is not taken into consideration.

Fig. 5. Zimm plot for fraction (110-4) (refer to Fig. 2).

そのまま利用すれば，大きな誤差を生ずる。Fig， 6 に は, 散乱角 $90^{\circ}$ 方向の見かけの散乱光のらち, ワルッ光 学製ガラスフィルターSY 44 を透過した光の波長分布 も同時に示してある*3。SY 44 フィルターを透過した光 


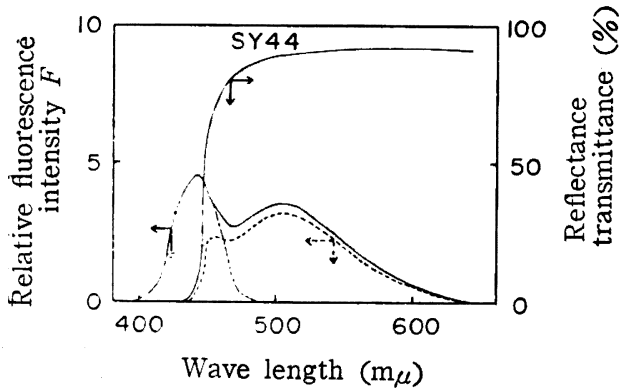

Solid line: Apparent transvered scattered light,

Dotted line: Transverse scattered light transmitted through SY 44 filter.

Reflectance transmittance is shown for comparison.

Fig. 6. Spectrum of apparent scattered light (incident beam: $436 \mathrm{~m}_{\mu}$ ) and it's transmitted portion through SY 44 filter.

のうち約 $15 \%$ は散乱光である。螢光を含む見かけの全 散乱光强度から, SY 44 フィルターの透過光をフィルタ 一の透過率を考虑して美し引いたものは, 散乱光たけか らなるがここれは散乱光全体の約 $75 \%$ が対応している にすぎない。そこで，散乱光と䀇光の偏光特性を別々に 測定して, Brice らの方法 ${ }^{10}$ を利用して螢光補正を行な った。

いま，入射光が自然光（u）で，見かけの散乱光 $(S)$ の垂直成分 (V) の還元散乱強度を $R_{V}^{u}(\theta)$, 水平成分 $(\mathrm{H})$ の還元散乱強度を $R_{H}{ }^{u}(\theta)$ とすると,

$$
\begin{aligned}
& R_{V}{ }^{u}(\theta)=\frac{I_{V, S}^{u}(\theta)+I^{u}{ }_{V, F}(\theta)}{I^{u}{ }_{V, t}\left(0^{\circ}\right)} \cdot \frac{r^{2}}{\sin \theta} \\
= & \frac{I^{u}{ }_{V, S}(\theta) \cdot r^{2}}{I^{u}{ }_{V, t}\left(0^{\circ}\right) \cdot \sin \theta}+\frac{I^{u}{ }_{V, F}(\theta) \cdot r^{2}}{I_{V, t}^{u}\left(0^{\circ}\right) \cdot \sin \theta} \\
& R_{H}{ }^{u}(\theta)=\frac{I^{u}{ }_{H, S}(\theta) \cdot r^{2}}{I^{u}{ }_{H, t}\left(0^{\circ}\right) \sin \theta}+\frac{I_{H, F}^{u}(\theta) \cdot r^{2}}{I_{H, t}^{u}\left(0^{\circ}\right) \sin \theta}(2)
\end{aligned}
$$

ここで, $I^{u}{ }_{V, S}(\theta), I^{u}{ }_{V, F}(\theta)$ は自然光を照射したとき, 散乱角 $(\theta)$ における散乱光 $(S)$ および螢光 $(F)$ の垂 直成分の強度, $I_{H, S}^{u}(\theta), I_{H, F}^{u}(\theta)$ は同様に水平成分 強度, $I^{u}{ }_{V, \ell}\left(0^{\circ}\right), I_{H, t}^{u}\left(0^{\circ}\right)$ は自然光を入射したときの, 見かけの透過光の垂直成分と水平成分強度である。

一方, 次式

$$
\begin{aligned}
& \rho_{u, S}=\frac{I_{H, S}^{u}\left(90^{\circ}\right)}{I_{V, S}^{u}\left(90^{\circ}\right)}=\frac{R_{H, S}^{u}\left(90^{\circ}\right)}{R_{V, S}^{u}\left(90^{\circ}\right)} \\
& \rho_{u, F}=\frac{I_{H, F}^{u}\left(90^{\circ}\right)}{I_{V, F}^{u}\left(90^{\circ}\right)}=\frac{R^{u}{ }_{H, F}\left(90^{\circ}\right)}{R_{V, F}^{u}\left(90^{\circ}\right)}
\end{aligned}
$$

で, 散乱成分と螢光成分の偏光解消度を定義し,

$$
I_{H, t}^{u}\left(0^{\circ}\right)=I_{V, t}^{u}\left(0^{\circ}\right)
$$

を考虑すると，

$$
\begin{gathered}
R_{V, S}^{u}(\theta)=\left(R^{u}(\theta)-\frac{R^{u}{ }_{H}(\theta)}{\rho_{u, F}}\right)\left(1-\frac{\rho_{u, S}}{\rho_{u, F}}\right)\left(\frac{1}{\sin \theta}\right) \\
R_{V, F}^{u}(\theta)=R_{V}^{u}(\theta)-R_{V, S}^{u}(\theta)
\end{gathered}
$$

が得られる。これより, あらかじめ $\rho_{u}, s, \rho_{u, F}$ が決めら れておれば， $R_{V}^{u}(\theta), R_{H}^{u}(\theta)$ を測定することによって $R_{V, S}^{u}(\theta)$ を評洒できる。

散乱光の偏光解消度 $\rho_{u, s}$ 之螢光解消度 $\rho_{u, F}$ は以下に 述べる方法で決定した。フィルターを七ルと光電管の間 に插入すると,たとえ sharply cut off フィルターを使 っても，營光成分は完全には透過されない(Fig. 6)。そ こで, フィルターの透過率を補正するため, 散乱光成分 を含まない $490 \mathrm{~m} \mu$ 以上の波長域にお汁る全散乱光強度 と SY 44 フィルター透過光強度の比 $k$ を Fig. 6 上り求 め, 1.12 を得た。フィルターの透過率の補正係数を $k$ で 近似した。ガラスフィルターの透過率は散乱光の偏光度 には影響されない。たからこの補正係数を透過光の各偏 光成分に乗ずればよい。ガラスフィルター透過光は一般 に 10 20\% の散乱光を含むか， $\rho_{u, F}$ の評価の際には散 乱光の混在は無視してよい(後述)から, $I^{u}{ }_{v, F}(\theta), I_{H, F}^{u}$ （）とSY 44 フィルター透過光強度 $I_{f}{ }^{\mu}(\theta)$ の間には

$$
I^{u}{ }_{V, F}\left(90^{\circ}\right)+I^{u}{ }_{H, F}\left(90^{\circ}\right)=I_{f}{ }^{u}\left(90^{\circ}\right) f k \simeq I_{f}{ }^{u}\left(90^{\circ}\right) k
$$$$
\text { または, }
$$

$$
\left.\begin{array}{l}
I^{u}{ }_{V, F}\left(90^{\circ}\right) \simeq I^{u}{ }_{V, f}\left(90^{\circ}\right) k \\
I^{u}{ }_{H, F}\left(90^{\circ}\right) \simeq I^{u}{ }_{H, f}\left(90^{\circ}\right) k
\end{array}\right\}
$$

ここで, $f$ は $I_{f}{ }_{f}\left(90^{\circ}\right)$ のらち螢光の占める割合である。 (8), (9)式より,

$$
\rho_{u, F}=\frac{I^{u}{ }_{H, F}\left(90^{\circ}\right)}{I_{V, F}^{u}\left(90^{\circ}\right)} \simeq \frac{I_{H, f}^{u}\left(90^{\circ}\right)}{I^{u}{ }_{V, f}\left(90^{\circ}\right)}
$$

見かけの散乱光強度の偏光成分を $I^{u}{ }_{V}(\theta), I^{u}{ }_{H}(\theta)$ で 表わすと，

$$
\begin{aligned}
& I^{u}{ }_{v, s}(\theta)=I^{u}{ }_{v}(\theta)-I^{u}{ }_{V \cdot f}(\theta)=I^{u}{ }_{v}(\theta)-I^{u}{ }_{V, f}(\theta) k f \\
& I^{u}{ }_{H, S}(\theta)=I^{u}{ }_{H}(\theta)-I_{H, F}^{u}(\theta)=I_{H}{ }^{u}(\theta) \\
& -I^{u}{ }_{H, f}(\theta) k f
\end{aligned}
$$

したがって,

$$
\begin{aligned}
\rho_{u, S} & =\frac{I^{u}{ }_{H}\left(90^{\circ}\right)-I^{u}{ }_{H, F}\left(90^{\circ}\right)}{I^{u}{ }_{V}\left(90^{\circ}\right)-I^{u}{ }_{V, F}\left(90^{\circ}\right)} \\
\simeq & \frac{I^{u}{ }_{H}\left(90^{\circ}\right)-I^{u}{ }_{H, f}\left(90^{\circ}\right) k}{I^{u}{ }_{V}\left(90^{\circ}\right)-I^{u}{ }_{v, f}\left(90^{\circ}\right) k}
\end{aligned}
$$

(10）式より $\rho_{u, F} か ゙ ，(13)$ 式より $\rho_{u, s}$ が評価できる。

なお，(10）式を利用して， $\rho_{u, F}$ を計算する際， フィ ルター透過光に混っている散乱光成分の寄与が無視でき るものとしている。これは次のような実験から確かめら れた。 $365 \mathrm{~m} \mu$ の光の入射によって励起された見かけの 散乱光を各々東芝製 LS-9, ワルッ光学製 SY-44フィル ターで透過させ, $I_{H, f}^{u}(\theta) / \Gamma^{u}{ }_{V, f}(\theta)$ を散乱角 $\theta=30 \sim$ 


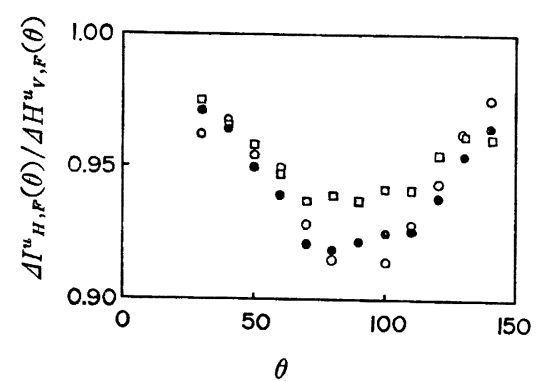

$\square: S-R(40),[\eta]=7.23$ (Filter SY -44 ),

-: S-R $(40),[\eta]=0.43$ (Filter LS-9),

O: S-R $(40),[\eta]=0.43$ (Filter SY-44)

Incident light: $365 \mathrm{~m}_{\mu}$

The filter (LS-9 or SY-44) was inserted between scattering cell and photomultiplier to exclude the scattered light form fluorescence completely (LS-9) or incompletely (SY-44). It is ascertained that the contamination of scattered light can be neglected in determining the depolarization factor of fluorescence.

Fig. 7. Angular dependence of the scattering ratio $\Delta I^{u}{ }_{H, F}(\theta) / \Delta I_{V, F}^{u}(\theta)$ for fractions.

$140^{\circ}$ の範囲で測定した。LS-9 の透過光には約 $20 \%$ の 散乱光が含まれているか， SY-44 透過光は散乱光成分 を全く含まない。その結果, $I^{u}{ }_{H, f}(\theta) / I^{u}{ }_{v, f}(\theta)$ は散乱 光の存在にはほとんど影響されなかった（Fig. 7)。

Fig. 7 にはPANに原因寸る螢光の偏光成分比

$$
\begin{aligned}
& \frac{\Delta I^{u}{ }_{H, F}(\theta)}{\Delta I_{V, F}^{u}(\theta)} \simeq \frac{\Delta I_{H, f}^{u}(\theta)}{\Delta I_{V, f}^{u}(\theta)} \\
& =\frac{\left(I^{u}{ }_{H, f}(\theta)\right)_{\text {soln }}-\left(I^{u}{ }_{H, f}(\theta)\right)_{\text {solv }}}{\left(I^{u}{ }_{v, f}(\theta)\right)_{\text {soln }}-\left(I^{u}{ }_{V, f}(\theta)\right)_{\text {solv }}} \\
& \simeq \frac{\left(I_{H, f}^{u}(\theta)\right)_{\text {soln }}}{\left(I_{V, f}^{u}(\theta)\right)_{\text {solv }}}
\end{aligned}
$$

をブロットしてある(ここで, soln, solv は各々溶液， 純溶媒に対する値を意味する)。この場合，溶媒の DMF は熄光を発しない（Fig. 18 参照）から, 溶萑の溃光は そのま PAN 分子に原因している。

$\Delta I_{H, F}^{u}(\theta) / \Delta I_{V, F}^{u}(\theta)$ は PAN の分子量には上らず, ほぼ同一の角度依存性を示す。螢光成分の偏光解消度 $\rho_{u, F}=\Delta I^{u}{ }_{H, F}\left(90^{\circ}\right) / \Delta I^{u}{ }_{V, F}\left(90^{\circ}\right)=0.92 \sim 0.94 \quad$ が得られ た。同粎にして, 入射光が $465 \mathrm{~m} \mu$ の場合, $\rho_{u, F}=0.80$ 〜0.86が得られた。入射光の波長を变えると, 偏光解 消度もわずか変化する。

(13)式から PAN の $\rho_{u, S}\left[\equiv\left\{\left(I_{H, S}^{u}\left(90^{\circ}\right)\right)_{\text {soln }}-\left(I_{H, S}^{u}\right.\right.\right.$ $\left.\left.\left(90^{\circ}\right)\right)_{\text {solv }}\right\} /\left\{\left(I^{n}{ }_{V, S}\left(90^{\circ}\right)\right)_{\text {soln }}-\left(I^{u}{ }_{V, S}\left(90^{\circ}\right)\right)_{\text {solv }}\right.$ 常計算 した結果， $\rho_{u, s}=0.01 \sim 0.02$ であった。 $\rho_{u, s}$ は試料の重 合方法, 分子量拉よびポリマー濃度にはほとんど影響さ れない（Fig. 8)。PAN の DMF 溶液の $\rho_{u}$ については，

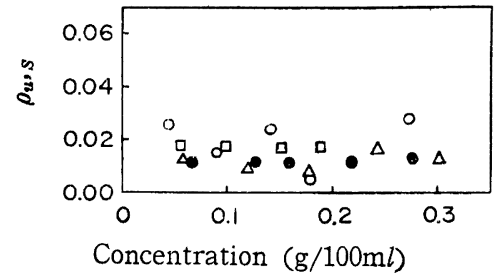

O: S-R $(40),[\eta]=1.48$,

$\Delta:$ S-R $(40),[\eta]=3.28$,

$\square:$ S-R $(40),[\eta]=7.08$,

- : P- $n \mathrm{R}(\mathrm{B}),[\eta]=6.0$.

It is ascertained that the depolarization factor of scattered light $\rho_{u, s}$ is $0.01 \sim 0.02$ irrespective of the conditions of polymerization, molecular weight and concentration.

Characteristic behabior of apparent depolariz. ation factor $\rho_{u, a p}$ (cf. Fig. 9) should not be interpreted in terms of the anisotropic proper. ties of optical segment, but of the contamination of fluorescence.

Fig. 8. Concentration dependence of depolarization factor of scattered light with incident beam of $436 \mathrm{~m}_{\mu}$ for PAN-DMF system at $20^{\circ} \mathrm{C}$.

現在までに Krigbaum-Kotliar'多が検討しただけである心 彼らによると, 未分別試料 $\left(\bar{M}_{n}=4.1 \times 10^{4}\right)$ で $\rho_{u}=0$ で あるのに対し, 分別試料 $\left(\bar{M}_{n}=6 \times 10^{4}, 1.06 \times 10^{5}\right)$ では $\rho_{u}=0.09$ となる。分子量分布によって $\rho_{u}$ が変化すると は考えられない。かりに, $\rho_{u}=0.09$ の值が信頼できるな らば, 後で述べるセダメントの光学的異方性を表わすパ ラメータ $\delta$ は約 0.01 となるから, Zimm プロットの際 $\Delta R_{U}{ }^{u}(\theta)$ を単に $\rho_{u}$ で補正しても， $c=0$ プロットは直 線とならないはずである (Fig. 10 参照)。しかし, 彼 らによると，Cabannes の因子を考虑しただけでZimm プロットの $c=0$ 曲線は直線となる (原報, Fig. 4)。 だから， $\rho_{u}=0.09$ の值には疑問がもたれる。本論文で 得た $\rho_{u}=0.01 \sim 0.02$ は他種の高分子物，たとえば， ア タクチックポリスチレン, ポリ酢酸ビニル, ポリ塩化ビ ニルなどについての報告値とほぼ一致している。

参考のために, 重合法をかえて得られた重合物溶液の. みかけの偏光解消度 $\rho_{u, a p}\left(\equiv \Delta I^{u}{ }_{H}\left(90^{\circ}\right) / \Delta I^{u}{ }_{V}\left(90^{\circ}\right)\right.$ $\left.=\Delta R^{u}{ }_{H}\left(90^{\circ}\right) / \Delta R^{u}{ }_{V}\left(90^{\circ}\right)\right)$ を Fig. 9 に示す。

$\rho_{u, a p}$ は非レドックス系沈股重合物>レドックス系水け 儿濁 $\left(40^{\circ} \mathrm{C}\right)$ 重合物>レドックス系水けん濁 $\left(-20^{\circ} \mathrm{C}\right)$. 重合物 ニ非レドックス系水けん濁重合物 の順に小さく なる。哂,ap は分子量の增加とともに減少する。 $\rho_{u, a p}$ はか。 なり大きくなることがあるから (Fig. 9), Fig. 4, Fig. 5 に示した Zimm プロットの異常性はセクメントの光: 学的簧方性に原因していると速断しがちである。しか. 


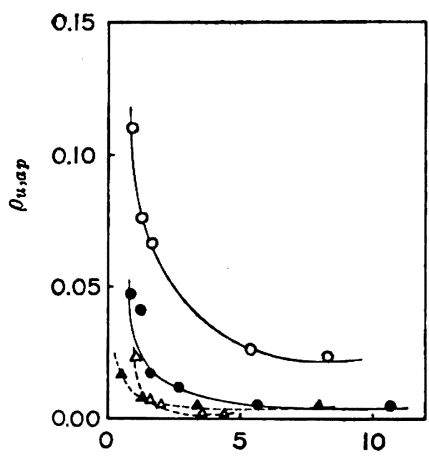

$\bar{M}_{w} \times 10^{-5}$

O: $\mathrm{P}-n \mathrm{R}(\mathrm{B})$,

A : $\mathrm{S}-\mathrm{R}(-20)$

- : S-R(40), $\Delta$ : S-nR,

$\rho_{u, a p}$ in which fluorescence is not separated from scattered light, decreases with molecular weight depending remarkably on the conditions of polymerization. It should not lead to the erroneous conclusion of expectating the predominant role of the anisotropy of optical segment.

Fig. 9. Molecular weight dependence of apparent depolarization factor $\rho_{u, a p}$ for fractions.

て，螢光成分を除いた散乱光の偏光解消度はほとんど無 視できるぐらい小さい（Fig. 8) からこの結論は明ら かに誤りである。

上述のようにして決定した $\rho_{u, s}, \rho_{u, F}$ を用い，(6) 式 から, $R_{V, S}^{u}(\theta)$ を求めた。

高分子鎖を構成する光学的セクメントの光学的異方性 が無視できないならば，内山一倉田 ${ }^{14)}$ の計算結果を利用 すると, 還元散乱強度 $\Delta R^{u}{ }_{V, s}(\theta)$ は次式で与えられる*4。 $\Delta R^{u}{ }_{V, s}(\theta)=K c M\left\{P(\theta)+2 A_{2} M Q(\theta) c+7 \delta+\cdots\right\}$ ここで,

$$
\begin{aligned}
& P(\theta)=1-\left(\frac{4}{3}\right)\left(\frac{2 \pi}{\lambda}\right)^{2} \overline{S^{2}} \sin ^{2}\left(\frac{\theta}{2}\right) \\
& \delta=\frac{\left(\frac{B}{A}\right)^{2}}{6 n} \\
& A=\frac{\left(a_{1}+a_{2}+a_{3}\right)}{3} \\
& \left.B^{2}=\frac{\left\{\left(a_{1}-a_{2}\right)^{2}+\left(a_{2}-a_{3}\right)^{2}+\left(a_{3}-a_{1}\right)^{2}\right\}}{15}\right\}
\end{aligned}
$$

$M$ は分子量, $c$ は濃度, $A_{2}$ は第 2 ビリアル係数, $Q(\theta)$ は分子間相関関数， $\delta$ はセクメントの光学的異方性を表 わすパラメーター, $\left(\overline{S_{2}}\right)^{1 / 2}$ は高分子鎖の重心半径, $n$ は 1 本の高分子鎖を構成している光学的セグメントの数,

\footnotetext{
*4たたし，原報と記号は一部異なる。
}

$a_{1}, a_{2}, a_{3}$ は光学的セクメントの分極率の主值である。 したがって，(15）式（16）式より

$$
\begin{aligned}
& \lim _{\theta \rightarrow 0} \frac{K c}{\Delta R_{V, S}^{u}(\theta)}=\frac{1}{\{M(1+7 \delta)\}}+\frac{2 A_{2} c}{(1+7 \delta)^{2}}-\cdots \\
& \lim _{c \rightarrow 0} \frac{K c}{\Delta R^{u}{ }_{V, S}(\theta)} \\
& =\left[\frac{1}{\{M(1+7 \delta)\}}\right]\left[1+\left(\frac{4}{3}\right)\left(\frac{2 \pi}{\lambda}\right)^{2} \frac{\sin ^{2}\left(\frac{\theta}{2}\right)}{1+7 \delta}-\cdots\right] \\
& \lim _{\substack{\theta \rightarrow 0 \\
c \rightarrow 0}} \frac{K c}{\Delta R^{u}{ }_{V, S}(\theta)}=\frac{1}{M(1+7 \delta)}
\end{aligned}
$$

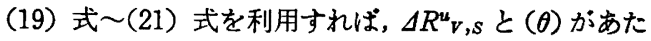
えられれば, Zimm プロットから， $\bar{M}_{w},\left(\bar{S}^{2}\right)_{2}, A_{2}$ が決 定できる。

なお, 偏光解消度 $\rho_{u, s}$ と $\delta$ との間には近似的に*6次式 が成り立つ。

$$
\begin{aligned}
\hline * 5 \text { 内山-倉田の原報 }(28) \text { 式 } \\
\\
\lim _{c \rightarrow 0} K c\left(\frac{1+\cos ^{2} \theta}{\Delta R^{u}(\theta)}\right) \\
=\left[\frac{1}{M(1+7 \delta)}\right]\left[1+\left(\frac{4}{3}\right)\left(\frac{2 \pi}{\lambda}\right)^{2} \sin ^{2}\left(\frac{\theta}{2}\right)\left\{\frac{\overline{S^{2}}}{(1+7 \delta)}\right.\right. \\
\left.-\left(\frac{3}{4}\right)\left(\frac{\lambda}{2 \pi}\right)^{2}\left(\frac{12 \delta}{1+7 \delta}\right) \cdots\right]
\end{aligned}
$$

は次式のまちがいである。

$$
\begin{aligned}
& \lim _{c \rightarrow 0} \frac{K c\left(1+\cos ^{2} \theta\right)}{\Delta R^{u}(\theta)} \\
= & {\left[\frac{1}{\left\{M\left(1+\frac{13 \delta+\delta \cos ^{2} \theta}{1+\cos ^{2} \theta}\right)\right\}}\right][1+\cdots] }
\end{aligned}
$$

または

$$
\begin{aligned}
& \lim _{c \rightarrow 0} \frac{K c\left(1+\cos ^{2} \theta\right)}{\Delta R_{U}^{u}(\theta)} \\
= & {\left[\frac{1}{\{M(1+7 \delta)\}}\right]\left[1+\left(\frac{4}{3}\right)\left(\frac{2 \pi}{\lambda}\right)^{2}\left\{\frac{\overline{S^{2}}}{(1+7 \delta)}\right.\right.} \\
- & \left.\left.\left(\frac{3}{4}\right)\left(\frac{\lambda}{2 \pi}\right)^{2} \frac{12 \delta(1+\cos \theta)}{(1+7 \delta)\left(1+\cos ^{2} \theta\right)}\right\}\left(\frac{\sin ^{2} \theta}{2}\right) \cdots\right]
\end{aligned}
$$

$(\mathrm{A} \cdot 1)$ 式は $\theta=0^{\circ}$ 以外は $(\mathrm{A} \cdot 2)$ 式または $(\mathrm{A} \cdot 3)$ 式に 一致しない。

$(\mathrm{A} \cdot 2)$ 式または $(\mathrm{A} \cdot 3)$ 式を利用して求めた $K c(1+$ $\left.\cos ^{2} \theta\right) / \Delta R^{u}{ }_{U}(\theta)$ 対 $\sin ^{2} \theta / 2$ プロットの $c \rightarrow 0$ への外捜 は, $\delta>0$ の場合には一般には直線とはならない。直線 からのずれは $(\mathrm{A} \cdot 1)$ 式の予測より著しい。 $\delta$ をいくつ か仮定した場合の $\lim _{a \rightarrow 0} K_{C}\left(1+\cos ^{2} \theta\right) / \Delta R^{u}{ }_{v}(\theta)$ 対 $\sin ^{2}$ $\theta / 2$ の関係を Fig. 10 に示す。 $\delta>3 \times 10^{-8}$ ではプロッ トは下に凸になり，もはや直線近似はできない。

*B(22) 式は

$$
\left(\frac{2}{3}\right)\left(\frac{2 \pi}{\lambda}\right)^{2} \overline{S^{2}} \gg 2 A_{2} M Q\left(90^{\circ}\right) c
$$

$(A \cdot 4)$ 
Table. 2. Comparison of the value of $\delta$ calculated from $\rho_{u}$ using eq. (22) with $\delta$ evaluated from $R^{h}{ }_{H}\left(90^{\circ}\right)$ for polystyrene in monochlorobenzene at $25.3^{\circ} \mathrm{C}(\lambda=436 \mathrm{~m} \mu)$.

\begin{tabular}{l|c|c|c|c|c|c|c}
\hline \hline Polymer & $\begin{array}{c}\text { Molecular } \\
\text { weight } \\
\times 10^{-5}\end{array}$ & $\begin{array}{c}\text { Unperturbed } \\
\text { radius of gyra- } \\
\text { tion } \overline{S_{0}^{2} \times 10^{12}} \\
\left(\mathrm{~cm}^{2}\right)\end{array}$ & $\begin{array}{c}\text { Expansion } \\
\text { factor } \\
\alpha_{\eta}\end{array}$ & $\begin{array}{c}\text { Radius of } \\
\text { gyration } \\
\overline{S^{2}} \times 10^{12} \\
\left(\mathrm{~cm}^{2}\right)\end{array}$ & $\begin{array}{l}\rho_{u} \\
\text { (observed) }\end{array}$ & $\begin{array}{c}\text { from } \\
\text { eq. }(22)\end{array}$ & from $R_{H}^{h}\left(90^{\circ}\right)$ \\
\hline Atactic & 5.12 & 4.17 & 3.0 & 38.7 & 0.029 & 0.00326 & 0.00086 \\
Isotactic & 3.59 & 3.38 & 2.9 & 29.3 & 0.3505 & 0.07029 & 0.0544 \\
\hline
\end{tabular}

$$
\delta=\frac{\rho_{u}}{6-7 \rho_{u}}\left[1+\left(\frac{2}{3}\right)\left(\frac{2 \pi}{\lambda}\right)^{2} \overline{S^{2}}\right]^{-1}
$$

（22）式を利用して， $\left(\overline{S^{2}}\right)^{1 / 2}=300 \AA ， 500 \AA$ と仮定した 場合の $\delta$ と $\rho_{u}$ との関係を Fig. 11 に示す。これより。 $\left(\overline{S^{2}}\right)^{1 / 2}$ の值にあまり関係なく, $\delta$ と $\rho_{u}$ との間には近似 的织

$$
\delta \simeq \frac{\rho_{u}}{10}
$$

がなりたつ。

本論文では $\delta$ の值を測定していない(いずれの場合で わるは間接的にしか評価できない)ので，(22）式を利用 して $\rho_{u, s}$ から $\delta$ を計算した。このため, まず(22) 式を用 いて $\rho_{u}, s$ から $\delta$ がの程度正確に求められるかを, 内 山一倉田のイソタクチックおよびアタクチックポリスチ レンーモノクロルベンゼン系 $\left(25.3^{\circ} \mathrm{C}\right)$ についての実験 データ $\left(\rho_{u}, \delta\right)$ から检討した。Table 2 に得られた結果 をまとめてある。内山一倉田の論文では $\overline{S^{2}}$ が直 接 報告 されていないので, アタクチックポリスチレンーモノク

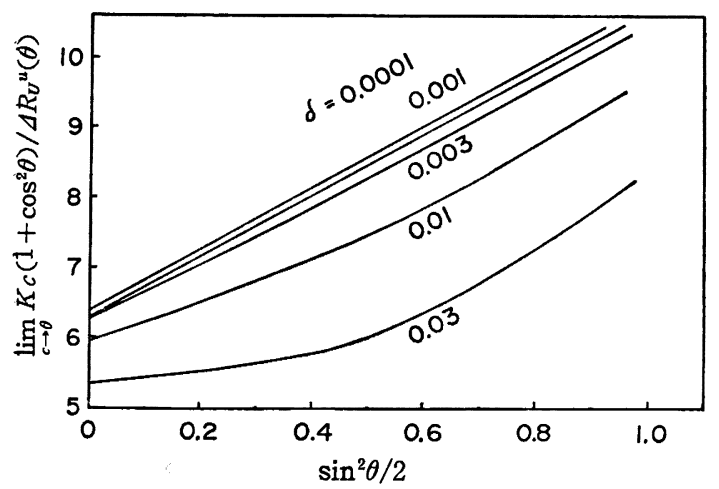

The incident beam: $436 \mathrm{~m}_{\mu},\left(\overline{S^{2}}\right)^{\frac{1}{2}}=500 \AA$ In the range $\delta \leq 1 \times 10^{-3}$, where, $\delta$ is a parameter of the anisotropy of optical segment defined in eq. (17) (see text), plot can be approximated by a straight line. The downward curvature is, however, obtained for $\delta>$ $3 \times 10^{-3}$.

Fig. 10. Plots of $\lim _{c \rightarrow 0} K c\left(1+\cos ^{2} \theta\right) / \Delta R_{U}{ }^{u}(\theta)$ against $\sin ^{2} \theta / 2$.

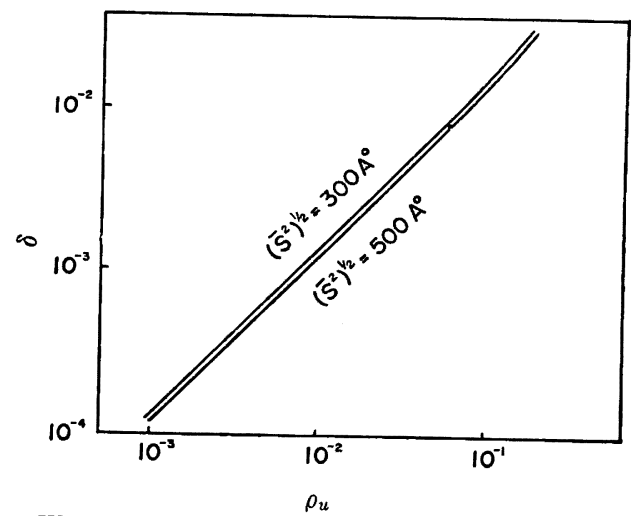

Wave length of the incident light: $436 \mathrm{~m}_{\mu}$, $\left(\overline{S^{2}}\right)^{\frac{1}{2}}=300$ or $500 \AA$. Effect of radius of gyra. tion on $\delta-\rho_{u}$ relation is almost negligible. $\delta \simeq 10^{-1} \rho_{u}$ is valid for polymer solutions in the range $\rho_{u}=10^{-8} \sim 10^{-1}$.

$\delta=1 \times 10^{-3} \sim 2 \times 10^{-3}$ is obtained from $\rho_{u}$ in Fig. 8 by use of eq. (22) for PAN-DMF system at $20^{\circ} \mathrm{C}$, and then, it becomes evident that the effect of anisotropy could cause the error by $0.3 \%$ on molecular weight and second virial coefficient.

Fig. 11. Theoretical relationships between $\delta$ and $\rho_{u}$.

ロルベンゼン系 $\left(25.7^{\circ} \mathrm{C}\right)$ の内山の粘度式 ${ }^{15)}$

$$
[\eta]=7.4 \times 10^{-5} \bar{M}_{w}^{0.75}
$$

および 0 溶媒中の粘度式（近似式）

$$
[\eta]_{0}=7.5 \times 10^{-4} \bar{M}_{w}{ }^{0.50} \text { (アタクチック) }
$$

または $[\eta]_{0}=9.0 \times 10^{-4} \bar{M}_{w}{ }^{0.50}$ (イソタクチック)

から出発し，以下の諸関係を利用して $\overline{S^{2}}$ を概算した。

$$
\begin{aligned}
& \alpha_{\eta}=\left(\frac{[\eta]}{[\eta]_{\theta}}\right)^{1 / 3} \\
& \left(\frac{\overline{r_{0}}}{M}\right)^{1 / 2}=6.5 \times 10^{-1} \AA \quad(\text { アタクチック) } \\
& \left(\frac{\overline{r_{0}^{2}}}{\bar{M}}\right)^{1 / 2}=7.0 \times 10^{-1} \AA \quad(\text { イタクチック) } \\
& \frac{\overline{r_{0}^{2}} \alpha_{\eta}{ }^{2}}{6} \cong \frac{\overline{r^{2}}}{6}=\overline{S_{0}{ }^{2}} \alpha_{\eta}{ }^{2}=\overline{S^{2}}
\end{aligned}
$$


Table 3. Comparisons of characteristic parameters of polyacrylonitrile in $\mathrm{N}, \mathrm{N}^{\prime}$-dimethylformamide at $20^{\circ} \mathrm{C}$ determined from light scattering measurements by using $546 \mathrm{~m} \mu$ and $436 \mathrm{~m}_{\mu}$ as incident light, respectively.

\begin{tabular}{|c|c|c|c|c|c|c|c|}
\hline Sample No. & $\lambda\left(\mathrm{m}_{\mu}\right)$ & $\lim _{\substack{c \rightarrow 0 \\
\theta \rightarrow 0}}$ & $\begin{array}{c}K c / R^{u}(\theta) \\
\times 10^{7}\end{array}$ & $\bar{M}_{w} \times 10^{4}$ & $A_{2} \times 10^{4}$ & $\left(\overline{S^{2}}\right)_{t}^{\frac{1}{2}}(\AA)$ & {$[\eta]$} \\
\hline $110-5$ & $\begin{array}{l}436 \\
546\end{array}$ & & $\begin{array}{l}103 \\
108 \\
\end{array}$ & $\begin{array}{l}9.8 \\
9.3 \\
\end{array}$ & $\begin{array}{l}22.9 \\
24.5 \\
\end{array}$ & $\begin{array}{l}154 \\
151 \\
\end{array}$ & 1.44 \\
\hline $110-4$ & $\begin{array}{l}436 \\
546\end{array}$ & & $\begin{array}{l}84.0 \\
83.2\end{array}$ & $\begin{array}{l}11.9 \\
12.0\end{array}$ & $\begin{array}{l}21.2 \\
21.4\end{array}$ & $\begin{array}{l}193 \\
190\end{array}$ & 1.91 \\
\hline
\end{tabular}

ここで, $\alpha_{\eta}$ は expansion factor, $\left(\overline{r_{0}^{2}}\right)^{1 / 2}$ は $\theta$ 溶媒中の 両端間 2 乗平均距離, $\left(\overline{S_{0}^{2}}\right)^{1 / 2}$ は $\theta$ 溶媒中の重心半径て ある。

Teble 2 から明らかなよらに，(22)式を利用して $\rho_{u, s}$ から求めた $\delta$ は $R_{H}^{v}\left(90^{\circ}\right)$ (入射光が垂直偏光の場合の $\theta=90^{\circ}$ 方向の散乱光の水平成分の還元散乱強度) から求 めた值とかなりょく一致する。 $R_{H}{ }^{v}(\theta), R_{V}^{n}(\theta)$ の実測 值が理論の予測*7に反して, $\theta$ によって変化するなどの 理諭と実験データとの不一致を考虑するならば，Table 2 で得られた程度の一致は十分満足すべきものである。

ここで，注意しなければならないのは， $R_{H}^{v}\left(90^{\circ}\right)$ ま たは類似の観測值から求められた $\delta_{\text {exp }}$ か，(17）式で定 義される $\delta$ に曘密には対応しないことである。といらの は, 光学的セグメントの主軸方向の分極率は常に正であ る*タか，（17）式の $\delta n$ に上限が生じて*9,

*7 理論によると, $R^{h}{ }_{V}(\theta)=R^{v}{ }_{H}(\theta)=K c M \cdot 3 \delta$ となっ $\tau, R_{V}{ }^{n}(\theta), R_{H}^{v}(\theta)$ は $\theta$ に無関係になる。

*9 光学的セクメントが $m$ 個のボンドより形成されてい

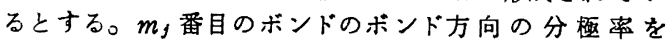
$\alpha_{m j 1}$, 垂㨁方向の分極率を $\alpha_{m j 2}$ とすれば，七クメントの 分極率の主值 $a_{i}$ は $\alpha_{m j 1}, \alpha_{m j 2}$ で昰き表わせて ${ }^{16)}$,

$$
a_{i}=\sum\left\{\left(\alpha_{m j 1}-\alpha_{m j 2}\right)\left(m_{j} i\right)^{2}-\alpha_{m j 2}\right\} \quad(\mathrm{A} \cdot 5)
$$

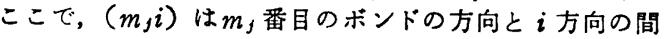
のた向余弦である。 $\alpha_{m j 1}>\alpha_{m f 2}>0$ が常に成立するから $(A \cdot 5)$ 式より $a_{t}>0$ となる。

*9（18）式の定義に従5と,

$$
\begin{aligned}
& \left(\frac{B}{A}\right)^{2}=\frac{3\left\{\left(a_{1}-a_{2}\right)^{2}+\left(a_{2}-a_{3}\right)^{2}+\left(a_{3}-a_{1}\right)^{2}\right\}}{5\left(a_{1}+a_{2}+a_{3}\right)^{2}} \\
= & \frac{6}{5}-\frac{18}{5} \frac{a_{1} a_{2}+a_{2} a_{3}+a_{3} a_{1}}{\left\{\left(a_{1}{ }^{2}+a_{2}{ }^{2}+a_{3}{ }^{2}+2\left(a_{1} a_{2}+a_{2} a_{3}+a_{3} a_{1}\right)\right\}\right.} \\
\leq & \text { (A. } 2 \text { (A) }
\end{aligned}
$$

$(A \cdot 6)$ 式と（17）式より，直らに（25）式が得られる。 *10 たとえば, Gotlib の理椧18)によると, 鎖の内部回転 が自由でも，ある程度制約されていても常に，統計 的セクメント数 $n$ 。は $n$ よりも小さい。イソタクチッ クポリスチレンの $n_{s}$ は $\bar{M}_{w}=10^{5}, 10^{8}$ に対して, 50 , $3.4 \times 10^{2}$ である。したがって, 明らかに $n_{s}>n_{n_{m x}} \simeq$ 4 となって, 理論の予測に反する。さらに, $n_{\text {max }} \simeq 4$ ではもはや高分子鎖をガウス鎖と近似できないから、 （16）式は利用できない。

$$
0 \leq \delta n \leq 0.2
$$

となる。(25) 式から， $\delta$ の値が既知であれば，1本の分 子鎖を構成するセグメント数の最大值 $n_{\max }$ が予測でき る。すなわち，現実の $n$ は $n_{\text {max }}$ を少なくとも越劣ては ならない。たとえば,イソタクチックポリスチレンでは $\delta=0.05$ が得られているから，(25）式より $n_{\text {max }} \simeq 4$ と なる。これは全く不合理な値である*10。結局, 光散乱 の実釦データとセクメントの異方性を考虑せずに導いた 理椧との不一致を,すべてセグメントの異方性に原因さ せることは妥当ではない。

PAN の螢光補正済の偏光解消度 $\rho_{u, s}$ は $0.01 \sim 0.02$ て ある。この值を利用して，(22）式から， $\delta$ を推定する と, $\delta=1 \sim 1.5 \times 10^{-3}$ が得られる。 $\delta$ を考慮しないで得 られた Zimm プロットから求められる見かけの分子量 $\bar{M}_{w r a p}$, 見かけの第 2 ビリアル係数 $A_{2, a p}$ とそれぞれの真 の値との間には

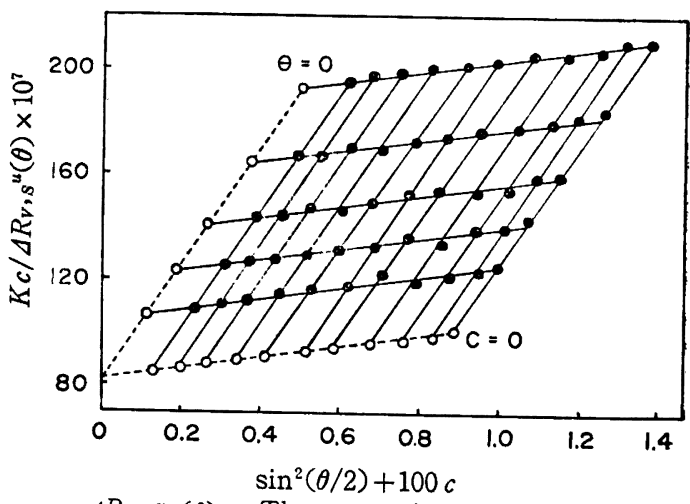

$\Delta R_{V, s^{u}}(\theta)$ : The scattering ratio of vertical component when incident light is unpolarized. Brice-Nutting-Halwer's method ${ }^{10}$ ) was used to correct for fluorescence. Zimm plot is now undistorted and the reasonable results are obtained.

Fig. 12. Zimm plot of vertical component of scattered light for fraction (110-4) (cf. Figs. 4 and 5). 


$$
\left.\begin{array}{l}
\bar{M}_{w, a p}=1.007 \bar{M}_{w} \\
A_{2, a p}=0.993 A_{2}
\end{array}\right\}
$$

の関係がある。だから，PANの場合セグメントの光学 的異方性を考虑しなくてよいことが確かめられる。事 実, 螢光を補正すれば, 正常な Zimm プロットが得ら れる。

Fig. 4, Fig. 5 で使用したのと同一の分別物について の $K c / \Delta R_{V}, s^{u}(\theta)$ 対 $\sin ^{2}(\theta / 2)+k c$ プロット（入射光, $436 \mathrm{~m} \mu$ を Fig. 12 に示す。 $\lim _{c \rightarrow 0} K c / \Delta R_{V}, s^{u}(\theta)$ 対 $\sin ^{2}$ $(\theta / 2)$ 曲線は明らかに直線となる。Fig. 12 と入射光 $536 \mathrm{~m} \mu$ の場合の Fig. 12 に相当するプロットから求め た $\bar{M}_{w}, A_{2},\left(\overline{S^{2}}\right)_{z}^{1 / 2}$ は実験誤差範囲内でよく一致した (Table 3)。

本論文では, 上述の方法に従って螢光補正を行ない, $K c / \Delta R_{V} s^{u}(\theta)$ 対 $\sin ^{2}(\theta / 2)+k c$ プロットから $\bar{M}_{w}$, $A_{2},\left(\overline{S^{2}}\right)_{2}{ }^{1 / 2}$ を決定した。

\section{5 溶液粘度}

ウペローデ型粘度計を用いて, 希釉法によって固有粘 度 $[\eta]$ を決定した。粘度測定に際して, 運動エネルギー 補正を行なった。 $\eta_{s p} / c$ または $\ln \eta_{r} / c\left(\eta_{s p}\right.$ ：比粘度， $\eta_{r}$ ：相対粘度）の濃度依存性を次式で仮定して，cに

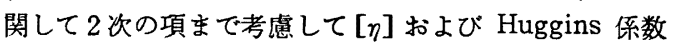
$k_{1}$ を求めた ${ }^{17) 。 ~}$

$$
\eta_{s p} / c=[\eta]+k_{1}[\eta]^{2} c+k_{2}[\eta]^{3} c^{2}+\cdots
$$

\section{3. 結 果}

3.1 Huggins 係数 $\boldsymbol{k}_{1}$ について

(27)式の係数 $k_{1}$ は分子の形態や，分子鎖と溶媒との

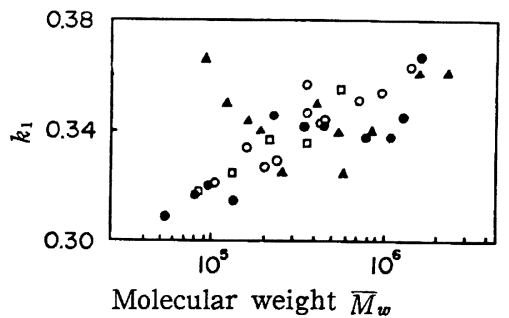

$\Delta: \mathrm{P}-n \mathrm{R}(\mathrm{B}), \quad \square: \mathrm{P}-n \mathrm{R}(\mathrm{H})$,

$\Delta:$ S-R (40), ๑: S-R $(-20)$,

O: $\mathrm{S}-n \mathrm{R}$

$k_{1}$ is determined by considering up to the concentration terms of $c^{2}$ in eq. (27).

$k_{1}$ decreases with increasing $\bar{M}_{w}$ for P-nR(B) fractions in the range of $\bar{M}_{w}$ smaller than $2 \times 10^{5}$. For other fractions, $k_{1}$ increases with $\bar{M}_{w}$.

Fig. 13. Molecular weight dependence of Hug. gins' parameter $k_{1}$.
間の相互作用などに関係する。一般に，良溶媒であるほ ど，分子鎖が硬いほど $k_{1}$ が小さくなることが知られて いるが, $k_{1}$ の物理的内容の詳細はまた不明である。

$k_{1}$ を分子量に対してプロットしたのが Fig. 13 であ る。ベンゼンを溶媒とする非レドックス触媒沈殿重合物 (P-nR(B)) を除いて, $k_{1}$ は $\log \vec{M}_{w}$ にほぼ比例する。 $(\mathrm{P}-n \mathrm{R}(\mathrm{B}))$ 重合物の $k_{1}$ は, $\bar{M}_{w}<2 \times 10^{5}$ の領域におい て, $\bar{M}_{w}$ の増加につれて減少する。

\section{2 固有粘度の分子量依存性}

固有粘度の分子量依存性は一般に次の実験式（いわゆ る Mark-Houwink-桜田式)

$$
[\eta]=K_{m} \bar{M}_{w}{ }^{a}
$$

で表現できる。ここで， $K_{m} ， a$ は高分子-溶媒系の組合 せによって実験的にきまる係数である。

PAN-DMF 系 $\left(20^{\circ} \mathrm{C}\right)$ の $[\eta]$ と $\bar{M}_{w}$ の対数プロット を Fig. 14 に示す。

ペンゼンを溶媒とする非レドックス触媒沈殿重合物 $(\mathrm{P}-n \mathrm{R}(\mathrm{B}))$ 以外の重合物 はほぼ 同一の $K_{m}, a$ を与之 る。

$$
[\eta]=4.66 \times 10^{-4} \bar{M}_{w}{ }^{0.71}
$$

(適用分子量範囲, $5.4 \times 10^{4} \sim$ 約 $1 \times 10^{6}$, 分別物, 試料 数 36)

\section{一方, 非レドックス沈殿重合物（ベンゼン溶液）は} $[\eta]=4.29 \times 10^{-4} \bar{M}_{w}{ }^{0.71}$

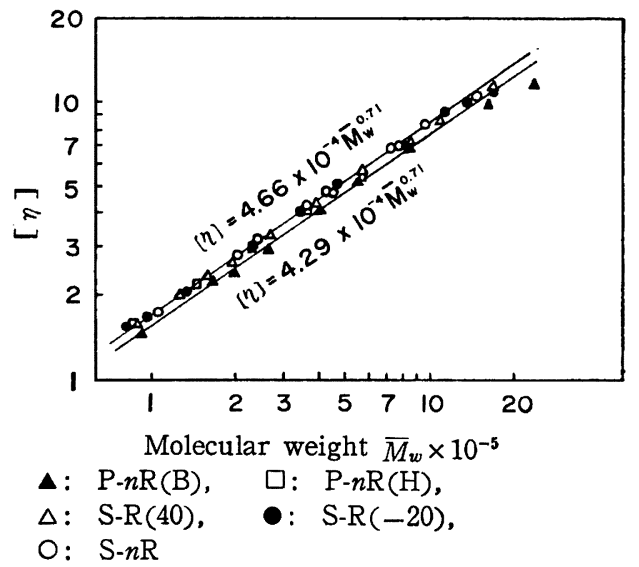

Fractions having molecular weight higher than $10^{6}$ are discarded in determing the parameters in the Mark-Houwink-Sakurada equations on the ground that experimental errors ocurring in intrinsic viscosity measurements become greater for higher molecular weight fractions. Solid lines are obtained by least. square method.

Fig. 14. Log-log plot of intrinsic viscosity and weight-average molecular weight at $20^{\circ} \mathrm{C}$. 
（適用分子量範囲， $9.3 \times 10^{4} \sim$ 約 $1 \times 10^{6}$, 分別物, 試料 数 11) で与兄られる。いずれの場合も， $\overline{M_{w}}>1 \times 10^{6}$ では 对数プロットが直線から下にずれるため, 粘度式の係数 を計算する対象とはしなかった。

PAN の $[\eta]-\overline{M_{w}}$ 関係は，高分子量側では粘度 式 〔(28) 式〕から下にずれることがすでに Peebles ${ }^{18)} に よ$ って指摘されている。彼は高分子量物が分岐構造をも。 と仮定して説明した。しかし, 重心半径の分子量依存性 は全分子量範囲にわたってべキの形で表現できる[(29) 式, Fig. 15 参照了 から, 分岐構造の存在は考之られな い。むしろ高分子量物の溶液では粘度のずり速度依存性 が著しく大きくなるためであろう。

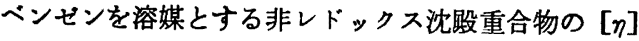
は, 同一分子量をむつ他の重合物と比較して, $8 \%$ 小さ い。非レドックス采沈殿重合物でも溶媒が $n$ ーヘプタン の場合には，その粘度式は他の重合法によって得られた も粘度の挙動は重合溶媒によって異なる。だから，粘度 式の違いは重合触媒（抢そらくは分子鎖末端の触媒残 基）の違いが原因ではなさそうである。

現在まで報告されている PAN - DMF 系の Mark重合物のそれと一致した。すなわち，同し触媒を用いて

Houwink-桜田式の係数 $K_{m}, a$ と適用粘度範囲, 分子 量測定法などをまとめて Table 4. 亿示す。Onyon 231 および藤崎 - 小林の報告") 以外は, 粘度式を決定するた めに利用した試料数か： 10 個以下である。Onyon の式 も分子量 (数平均分子量 $\bar{M}_{n}$ ) $1.6 \times 10^{5}$ を境に重合法の 異なる末分別物を利用している。たから，分子の微細構 造やその分布などが重合法によって異なり，そのために 粘度式が変化することがあれば（事実, その 1 例が本論 文で示された）Onyon の式の係数のむつ意味ははっき りしなくなる。原報のプロット（文献 23），Fig. 2) も $\bar{M}_{n} \simeq 1.6 \times 10^{5}$ を境にその勾配（三a）か変化してい る。

過去十数年にわたる多くの研究にもかかわらず, PAN の DMF 溶液の粘度式 [(28) 式]の係数が報告者によっ て一致しない。これは以下の諸理由による。

1）重合機構の異なる重合物を利用している。

2）分子量分別が困難でちる。

3）分子量決定がむずかしい（たとえば，溶液の唀 压は重合物の末端基によって影響されるし8（4.1参照） 光散乱には螢光が混在している)。

したがって,これらの諸因子を詳細に考應しないで粘 Table 4. Parameters in Mark-Houwink-Sakurada equation for polyacrylonitrile in dimethylformamide.

\begin{tabular}{|c|c|c|c|c|c|c|c|}
\hline$[\eta]$ range & $\left|\begin{array}{l}\text { Tempera- } \\
\text { ture }\left({ }^{\circ} \mathrm{C}\right)\end{array}\right|$ & $\mid K_{m} \times 10^{4}$ & $a$ & Method & Fraction or whole & Sample No. & Author \\
\hline $1.11 \sim 4.05$ & \begin{tabular}{|l|} 
no discri \\
ption
\end{tabular} & 17.5 & 0.66 & $\mathrm{OS}^{\mathrm{a})}$ & $\mathrm{F}$ & 9 & Houtz $(1950)^{191}$ \\
\hline $1.02 \sim 3.96$ & & 25.0 & 0.66 & OS & $W(A)^{b)}$ & & Frind $(1954)^{201}$ \\
\hline $1.08 \sim 4.26$ & 25 & 1.66 & 0.81 & $\underset{D^{d \prime}}{\mathrm{SD}^{\mathrm{el}}+}$ & $F(A)$ & 4 & Bisschops (1955) ${ }^{21}$ \\
\hline $0.25 \sim 4.35$ & & $0.66^{\ominus 1}$ & $0.99^{\mathrm{e})}$ & OS & $F(A)$ & & $\begin{array}{l}\text { Ciampa-Schwindt } \\
(1955)^{221}\end{array}$ \\
\hline $0.53 \sim 2.74$ & 25 & 2.43 & 0.75 & $\mathrm{LS}^{\prime \prime}$ & $\left.W(S)^{8}\right)$ & 4 & $\begin{array}{l}\text { Cleland-Stockmayer } \\
(1955)^{9)}\end{array}$ \\
\hline $0.72 \sim 12.3$ & 25 & 3.92 & 0.75 & OS & $W(S)$ & 16 & Onyon $(1956)^{24)}$ \\
\hline $1.21 \sim 2.20$ & 25 & 1.55 & 0.80 & OS & & 13 & $\begin{array}{l}\text { Krigbaum-Kotliar } \\
\left.\qquad(1958)^{8}\right)\end{array}$ \\
\hline $0.66 \sim 6.55$ & 35 & 2.78 & 0.76 & $\mathrm{D}+\mathrm{V}^{\mathrm{b})}$ & $F(A)$ & 9 & Kobayashi $(1959)^{24)}$ \\
\hline $0.80 \sim 3.20$ & 20 & 1.77 & 0.79 & SD & $F(A)$ & 6 & $\begin{array}{l}\text { Scholtan-Marzolph } \\
\qquad(1962)^{26)}\end{array}$ \\
\hline $1.56 \sim 7.91$ & 53 & 3.17 & 0.746 & LS & $F(A)$ & 13 & $\begin{array}{l}\text { Fujisaki-Kobayashi } \\
(1962)^{11}\end{array}$ \\
\hline $0.515 \sim 0.953$ & 20 & 3.59 & 0.742 & LS & $F(A)$ & 6 & $\begin{array}{l}\text { Fujisaki-Kobayashi } \\
(1962)^{25)}\end{array}$ \\
\hline $0.74 \sim 3.39$ & 30 & 2.96 & 0.74 & SD & $F(A)$ & & Inagaki et al $(1965)^{2)}$ \\
\hline $0.86 \sim 3.05$ & 30 & 2.09 & 0.76 & SD & $F(A)$ & 7 & Inagaki et al (1965) \\
\hline $1.24 \sim 11.1$ & 20 & 4.66 & 0.71 & LS & $F(A)+$ & 36 & This work (1967) \\
\hline $1.44 \sim 6.87$ & 20 & 4. 29 & 0.71 & LS & $F(P \cdot n R(B))^{\prime \prime}$ & 11 & This work (1967) \\
\hline
\end{tabular}

a) Osmotic pressure, b) Aqueous system, c) Sedimentation, d) Diffusion, e) Calculated by FujisakiKobayashi from the original data, f) Light scattering, g) Solution, h) Viscosity, i) Precipitation, j) See Table 1 
度式の一致のみを議論するのは意味がない。

\section{3 重心半径の分子量依存性}

高分子鎖の重心半径 $\left(\overline{S^{2}}\right)_{z}^{1 / 2}$ の分子量依存性を Fig. 15. に示す。 $\left(\bar{S}^{2}\right)_{z}^{1 / 2}$ は $\bar{M}_{w}$ とべキの関係

$$
\left(\bar{S}^{2}\right)_{z}^{1 / 2}=K_{s} \bar{M}_{w}^{a s}
$$

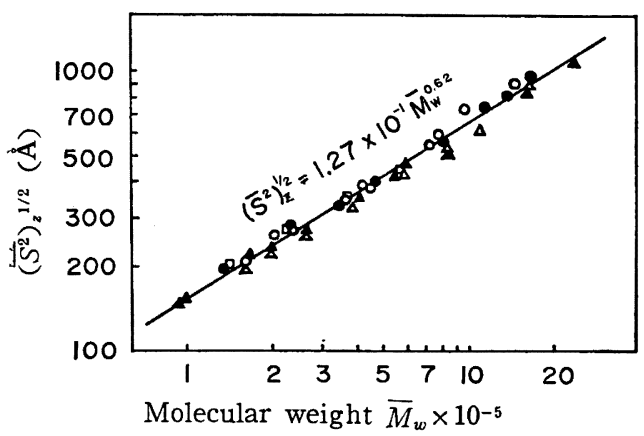

$\Delta: \mathrm{P}-n \mathrm{R}(\mathrm{B}), \square: \mathrm{P}-n \mathrm{R}(\mathrm{H}), \Delta ; \mathrm{S}-\mathrm{R}(40)$,

-:S-R(-20), O: S-nR.

Solid line is obtained by least spuare method.

Fig. 15. Log-log plot of the radius of gyration and weight-average molecular weight for PAN-DMF system at $20^{\circ} \mathrm{C}$.

炕あって, その倸数 $K_{s}, a_{s}$ は重合方法によって影響さ れない。すなわち，実験的に

$$
\left(\bar{S}^{2}\right)_{2}{ }^{1 / 2}(\AA)=1.27 \times 10^{-1} \bar{M}_{w}{ }^{0.62}
$$

(分子量範囲 $5.4 \times 10^{4} \sim 2.32 \times 10^{6}$, 分別物, 試料数 48 ) が得られた。

いま，のの $\alpha$ 依存性とす好効果がともに無視でき るならば， $a_{s}$ と $a$ との間には次の関係がある。 $\alpha_{n} / \alpha=$ 一定 ならば（ここで, $\left.\left.\alpha^{2}=\overline{(S}^{2}\right) /\left(\bar{S}_{0}{ }^{2}\right)\right)$

$$
a_{8}=\frac{(1+a)}{3}
$$

$\alpha_{\eta}^{3}=\alpha^{2 \cdot 43}$ ならば,

$$
a_{s}=\frac{(0.72+a)}{2.43}
$$

$a$ の実測値（0.71）を上式に代入すると（30）式より $a_{s}=0.57$, (31) 式より $a_{s}=0.59$ を得た。いずれも, 実 験值 0.62 よりやや小さい。

[ $\eta],\left(\overline{S^{2}}\right)_{z}^{1 / 2}$ が, (28) 式, (29) 式を満足するなら ば, $[\eta]$ と $\left(\bar{S}^{2}\right)_{2}{ }^{1 / 2}$ との間には,

$$
[\eta]=K_{r}\left(\overline{S^{2}}\right)_{z}^{1 / 2 \cdot \gamma}
$$

ここで, $r$ と $a$ との間には次の関係がなりたつ。

$$
\begin{aligned}
& \alpha_{\eta} / \alpha=\text { 一定 ならば, } \\
& \gamma=\frac{3 a}{(1+a)} \\
& \alpha_{\eta}^{3}=\alpha^{2 \cdot 43} \text { ならば, } \\
& \gamma=\frac{2.43 a}{(0.72+a)}
\end{aligned}
$$

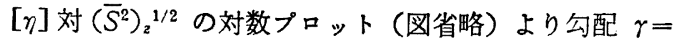
1.26 を得る。(28) 式の $a(0.71)$ を（33）式，(34) 式 に代入すると, 各々, $\gamma=1.25,1.21$ を得る。(33) 式が 実験値とほとんど一致した。

結局, $a_{s}$ と $a$ との関係は $\alpha_{\eta}{ }^{3}=\alpha^{2 \cdot 34}$ と仮定する方が 合理的であるのに対し， $r$ と $a$ との関倸は $\alpha_{r} / \alpha$ を一 定とみなした方がよく説明できる。したがって，この結 果だけからはどちらの関倸が妥当であるかは判断できな い。いずれの場合も，すぬけ効果は無視できる。

\section{4 第 2 ビリアル係数の分子量依存性}

第 2 ビทフル係数 $A_{2}$ の分子量依存性は一般に次式で 表現される。

$$
A_{2}=K_{a} \bar{M}_{w}^{-\nu}
$$

ここで, レは一定温度の高分子一溶媒系に対しては定数 となる。

PAN-DMF 系 $\left(20^{\circ} \mathrm{C}\right)$ Kついて, $5.4 \times 10^{4} \leq \bar{M}_{w} \leq$ $2.32 \times 10^{6}$. の分子量範囲に颃いて,

$$
A_{2}\left(\mathrm{ml} / \mathrm{g}^{2}\right)=4.94 \times 10^{-2} \bar{M}_{w}{ }^{-0.27}
$$

が得られた（Fig. 16）。 $A_{2}$ に及注す重合方法の影響は 明らかでない。

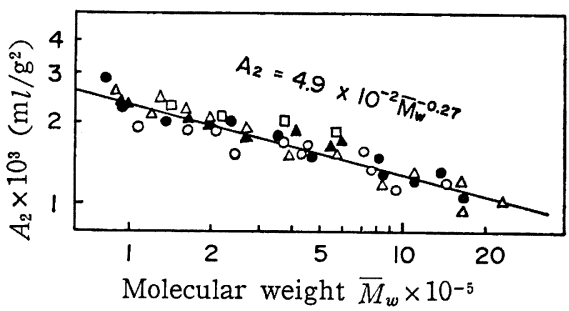

$\Delta: \mathrm{P}-n \mathrm{R}(\mathrm{B}), \square: \mathrm{P}-n \mathrm{R}(\mathrm{H}), \Delta: \mathrm{S}-\mathrm{R}(40)$,

- : S-R $(-20)$, O: S- $n \mathrm{R}$

Fig. 16. Log-log plot of the second virial coefficient $A_{2}$ and weight-average molecular weight for PAN-DMF system at $20^{\circ} \mathrm{C}$.

むし, $A_{2} \bar{M}_{w} /[\eta]$ の分子量依存性が次式

$$
\frac{A_{2} \bar{M}_{w}}{[\eta]} \propto M^{*}
$$

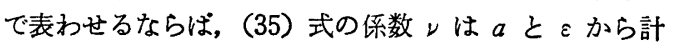
算できて,

$$
\nu=1-a-\varepsilon
$$

$A_{2} \bar{M}_{w} /[\eta]$ 対 $\bar{M}_{w}$ の対数-対数プロット（図省略）上 り $\varepsilon=0.01 \sim 0.02$ が得られる。したがって, (37) 式 より $\nu=0.27 \sim 0.28$ が求められた。この值は実測値と かなり良く一致する。

\section{4. 考 察}

\section{1 ポリアクリロニトリル溶液の螢光}

2.3 で述べたよらに, PANのDMF 溶液は螢光を発す る。敩密には, 螢光スペクトルは励起光（この場合，入 
射光）の波長に無関係に常に一定の波長をもつはずであ る。ところで, PAN-DMF 系に見られる螢光のピーク 波長は入射光の波長によって变化する。たとえば，レド ックス重合物溶液に各々 $365 \mathrm{~m} \mu, 436 \mathrm{~m} \mu, 546 \mathrm{~m} \mu$ の 光を入射すると, $412 \mathrm{~m} \mu, 495 \mathrm{~m} \mu, 580 \mathrm{~m} \mu$ にピーク をもつ螢光がでる (Fig. 19 参照)。螢光は入射光よりも $30 \sim 50 \mathrm{~m} \mu$ 長波長にずれている。現在のところ,その理 由*11 は不明である。

DMF 以外の溶媒に PANを溶解させても螢光が出る。 それらの螢光波長は溶媒の種類にほとんど影響されな い。Fig. 17 K PAN の各種溶液の螢光エネルギー分布 を示す。螢光スペクトルは振動構造をもたない。PAN

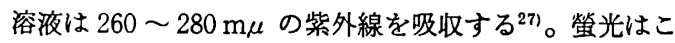
○紫外吸収とほぼ鏡像の関係にある。PAN 溶液の螢光

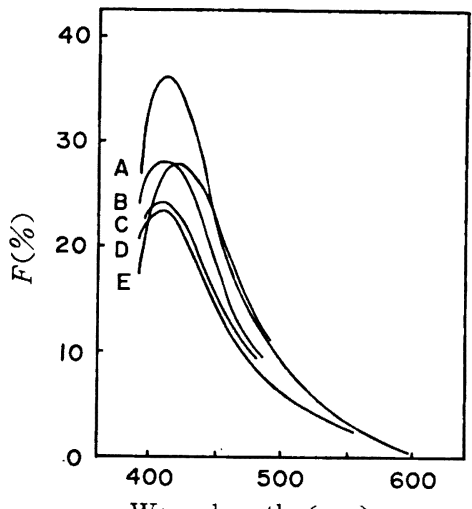

Wave length $\left(\mathrm{m}_{\mu}\right)$

A : Dimethylsulfoxide, B: Dimethylformamide, C : $\gamma$-Buthylolactone, D: Ethylene carbonate, E : $60 / 40$ Sodium perchlorate/Water Incident light $365 \mathrm{~m}_{\mu}$, Concentration $1 \mathrm{~g} / 100 \mathrm{~m} l$ Polymer S-R (40)

Relative fluorescence spectra $F$ is defined in Fig.3.

Fig. 17. Fluorescence spectra of polyacrylonitrile in various solvents.

*11 入射光の波長が变わると螢光効率が大きく変わる と仮定するならば，入射光の波長を变えることに よって励起される螢光物質が異なる。そうすれば 䖝光波長も変わる。

*12 酸了ミド基, カルボニル基などは, いわゆる助螢 光団であるから螢光の発現に正の寄与をするとし ても，その役割は小さい。

*13 酸の添加によって, $~ \mathrm{SO}_{3} \mathrm{H}+\mathrm{H}^{+} \rightarrow \sim \mathrm{SO}_{3} \mathrm{H}_{2}{ }^{+}$, フルカリの添加によって, $\sim \mathrm{SO}_{3} \mathrm{H}+\mathrm{OH}^{-} \rightarrow$

$$
\sim \mathrm{SO}_{3}{ }^{-}+\mathrm{H}_{2} \mathrm{O}
$$

とスルホン基が变化し， $\mathrm{SO}_{3} \mathrm{H}_{2}{ }^{+}$のとき螢光が 強くなると考えられる。

*14 たとえば, $\mathrm{C}_{6} \mathrm{H}_{5}-\mathrm{CH}=\mathrm{C}(\mathrm{CN}) \sim$ など
はほとんどPAN 分子に原因する。

螢光強度は重合体の重合条件之分子量に著しく影響さ れる。したがって, 螢光は PAN の - $\left(\mathrm{CH}_{2}-\mathrm{CHCN}\right)_{n}$ - 構 造に基くのではない。むしろ，高分子鎖の一部を構成し ている,きわめて微量の異種構造（末端基を含めて）が 螢光の原因であろら。

螢光強度を同一分子量で比較すると, ベンゼン中非レ

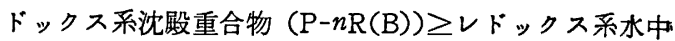
けん濁重合物 (S-R(40))> 非レドックス系水中けん濁 重合物 (S- $n \mathrm{R})$ の順に小さくなる。ベンゼン中非レド ックス系沈殿重合物の螢光強度は, レドックス系水中け ん濁重合物のそれに比較すると, 高分子量領域では同程 度であるが，低分子量測でははるかに大きい。このこと は, 見かけの偏光解消度 $\rho_{u, a p}$ の重合条件依存性とよく 一致する (Fig. 9. 参照)。

2.3.2 において, PANの異種構造として酸アミド, カルボン酸またはそのェステルをIR スペクトルから検 出した。これらの含有量は重合方法によって異なるが,そ の序列はちょうど螢光強度のそれと逆になる。たから,カ ルボニル基が螢光の原因であると単純にはいえない*12。

レドックス重合物溶液に酸を添加すると, 螢光強度が 增す (酸による負の消光効果)。一方，水酸化ナトリウ ムを添加すると, 螢光強度は可逆的に減少する（アルカ リによる正の消光効果)。レドックス重 合物はその分子 鎖の末端にスルホン酸基 ( $\mathrm{SO}_{3} \mathrm{H}$ または $\mathrm{SO}_{3} \mathrm{Na}$ など) を もつ。これらの実験事実より，末端にある触媒残基が螢 光の原因*13 であって, この場合，罃光はイオン型であ る。

ベンゼン中非レドックス系沈殿重合物はいちばん強い 螢光をもつ。この場合, 酸またはアルカリの添加効果は 全く認められない。この螢光は非イオン型である。同じ 触媒を用いた $n$-ヘプタン中沈显重合物は, 螢光強度が非 常に小さい。これより，ベンゼン中重合物のもつ強い螢 光は重合開始剤残基のせいではない。溶媒としてのベン ゼンが螢光に関係しているようである。 $n$-ヘブタンま たはnーヘプチル基は螢光をもたないのに対し，ペンゼン はそれ自身䖝光団である。ベンゼン中でアゾビスイソブ チロニトリルを開始剤とするアクリロニトリルの $60^{\circ} \mathrm{C}$ 重合においては, 溶媒への連鎖移動が、スチレンやメ夕 クリル酸メチルの重合の場合に比較して, はるかに起こ クやすい 27)。Das ら ${ }^{27)}$ は, ベンゼンへの連鎖移動係数 として $2.46 \times 10^{-3}$ を得ている。したがって,ポリマーラ ジカルのベンゼンへの連鎖移動が起こり，その結果ベン ゼン環が主鎖の末端に導入される可能性がある。ベンせ ン環の主鎖への導入の仕方次第によっては, 強い螢光を 発するよらになりらる*14。

イオン型と非イオン型では当然螢光性や螢光波長が異 なる。 
入射光が $365 \mathrm{~m} \mu$ の場合の見かけの散乱光の波長分布 を Fig. 18 に示す。測定は島津螢光励起装置 GF-16 E 形と島津自記光電分光光度計 SV-50A 形とを組合せて 行なわれた。螢光波長は重合物の重合条件（特に, 重合 触媒と溶媒）に著しく影響される。ただ，この場合， 溶液は光散乱測定の場合ほどには精製しなかったので Fig. 18 の散乱光強度は真の散乱光ではない。Fig. 18

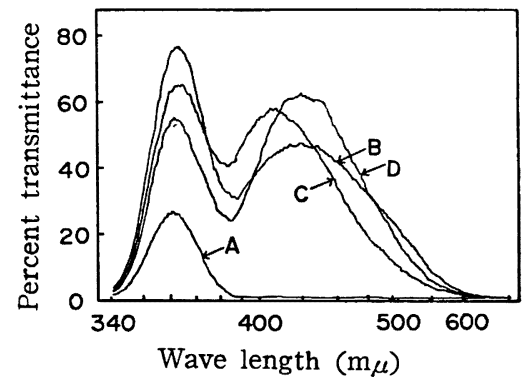

Incident light: $365 \pm 20 \mathrm{~m}_{\mu}$, Wave length at peak of fluorescence differs with the conditions of polymerization. $\mathrm{A}: \mathrm{DMF}, \mathrm{B}: \mathrm{P}-n \mathrm{R}(\mathrm{B}), \mathrm{C}$ : S-R(40), D: S- $n \mathrm{R}$

Fig. 18. Spectra of the apparent scattered light for whole polymers.

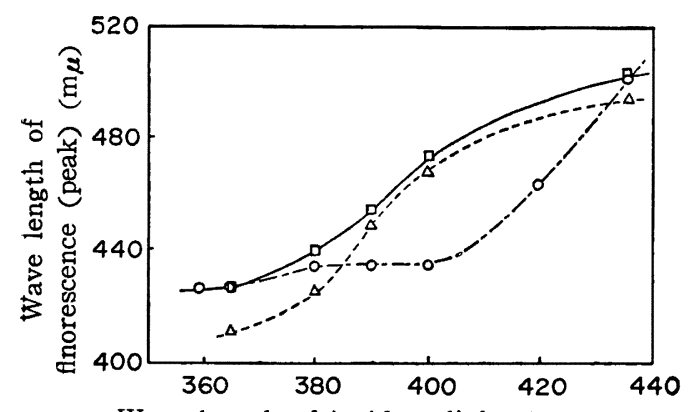

Wave length of incident light $\left(\mathrm{m}_{\mu}\right)$

$\square: \mathrm{P}-n \mathrm{R}(\mathrm{B})$ whole polymer, $\mathrm{O}: \mathrm{S}-n \mathrm{R}$ whole polymer, $\triangle: S-R(40)$ whole polymer

Fig. 19. Relationships between wave length of incident light and that of fluorescence.

*15 著者らは, PAN $\overline{(M}_{w}=3.45 \times 10^{5}$, 分別物) エチ レンカーボネート水溶夜（エチレンカーボネー ト : 水 $=85: 15$, 重量比) の光散乱测定を行ない $A_{2}=0$ が成立する温度として $44^{\circ} \mathrm{C}$ を得た。 こ の温度における $\bar{M}_{w}=3.45 \times 10^{5}$ のエチレンカー ボネート水溶液の $[\eta]=1.98, \mathrm{DMF}\left(20^{\circ} \mathrm{C}\right)$ 溶 液における $[\eta]=3.855$ である。これより, 試料 の DMF 溶液の expansion factor $\alpha_{\eta}$ を計算す ると 1.95 を得る。混合溶媒系を利用しているか ら, $A_{2}=0$ を満足する温度でも, 緟密には $\theta$ 温度 ではないが、これより $\alpha_{\eta}$ の目安が得られる。
では，螢光波長が重合触媒だけで決定されるようにみえ る。しかし, 励起光波長を変えて螢光波長分布を测定す ると (Fig. 19), 螢光波長の励起光依存性は重合溶媒に よっても変わることが確かめられる。さらに，入射光が $365 \mathrm{~m} \mu$ の場合には, 同程度の螢光をもつレドックス重 合物とベンゼンを溶媒とする沈殿重合物でも， $546 \mathrm{~m} \mu$ を入射すると前者では螢光が無視できるのに対し，後者 の螢光は決して無視できないことも, 螢光構造の違いと して理解できる。

䃕光桡造の詳細な同定はまだできていない。最も強い 螢光をもつ重合物 $(\mathrm{P}-n \mathrm{R}(\mathrm{B}))$ は溶液物性の点でも二三 の特異な性質をもつ。したがって, $(\mathrm{P}-n \mathrm{R}(\mathrm{B}))$ 重合体の 溶液物性の特異性はその重合体の螢光構造との間になん らかの関連性が期待される (4.3 参照)。

Krigbaum-Kotliar ${ }^{81}$ によると, 過硫酸塩 - 次覀 硫酸 塩を開始剤とするレドックス系けん濁重合物（本論文の S-R 重合物と一致) の DMF 溶液の浸透压測定から求め た数平均分子量 $\bar{M}_{n}$ は, $\mathrm{DMF}$ の調製法によって変化す る。すなわち, 蒸留 DMF を非イオン化すると $\bar{M}_{n}$ は增 加する。臭化りチウム, または臭化トリメチルアンモ二 ウムを $\mathrm{DMF}$ 溶液に添加すると， $\bar{M}_{n}$ は著しく大きくな る。この特性は, レドックス重合物に特有のものであっ て, アゾブチロニトリルを開始剤とする溶液重合物（本 論文の $(\mathrm{P}-n \mathrm{R})$ 重合物に類似のもの）溶液では見出さ れない。このことより,レドックス重合体溶液のある種 の性質はイオンの影響を受けやすいのに反し, 非レドッ クス采溶液重合物（抢そらくは沈貶重合物も）は非イオ ン的である。前者の分子の末端にはイオン化しやすい触 媒残基 (- $\mathrm{SO}_{3} \mathrm{H}$ など) が存在する。一方, 後者の分子末 端の触媒残 基は全くイオン化しないことが関係してい る。本諭文で見出された螢光特性のイオン性, 非イオン 性の重合条件による変化も Krigbaum-Kotliar の結果 と密接な関連がある。

\section{2 ポリアクリロニトリルの Unperturbed dimen- sion}

PAN の $\theta$ 溶媒*15 はまた混合溶媒 ${ }^{26)}$ 以外見出されてい ない。PAN は大きな極性をもつから，将来においても 実験的に $\theta$ 溶媒としての単溶媒は求めにくい。したかっっ て, $\theta$ 溶媒について光散乱実験を行なって, 直接 unperturbed dimension を評価することはできない。そこで, 良溶媒中の溶液物性から unperturbed dimension を決 定しなければならない。

良溶媒中の溶液物性から unperturbed dimension 評洒する方法が近年多数提案されている。すなわち,

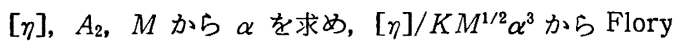
定数 $K\left(\equiv \emptyset_{0}\left(\overline{r_{0}^{2}} / M\right)^{3 / 2}, \emptyset_{0}\right.$ は Flory パラメーター) を決定する Krigbaum 法 ${ }^{281}$ ，それにすねけ效果を考虑 したその改良法 ${ }^{291}$ ，倉田らの方法 ${ }^{301}$, 各種溶媒にお゙ける 
粘度式 [(28) 式]の組合せから $K$ を求める上出らの方 法 $^{31,32)},[\eta]$ ¿ $M$ から $K$ を評価する Flory-Fox ${ }^{331}$, Stockmayer-Fixman (S-F) ${ }^{31}$. Kurata-Stockmayer ${ }^{34)}$,

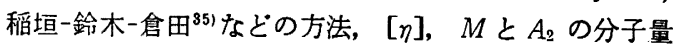
依存性を考虑した Bohdanecky の方法年)，その改良 法 ${ }^{37}$, 粘度 $\eta$ の濃度依存性と $M$ から $\left(\bar{r}_{0}^{2}\right)^{1 / 2}$ を求める Cornet の方法 ${ }^{381}$ などがある。これらの理論はそれぞれ 異なる仮定を含むから, どの方法がより妥当であるかを 検討寸るには，あくまで実験データとの対比においてな される必要がある。Cornet の方法尔を除いて，これら の方法によって決定されるのは Flory 定数 $K$ であって unperturbed dimension $\left(\left(\bar{r}_{0}^{2}\right)^{1 / 2}\right.$ または $\left.\left(\bar{S}_{0}^{2}\right)^{1 / 2}\right)$ そ のものではない。

一般に， $[\eta] ， M$ に比較して， $A_{2}$ の测定精度は低い。 さらに, $A_{2} M /[\eta]$ と $\alpha$ を結びつける理諭も特に良溶媒 側では完全ではない。このため, $A_{2} M /[\eta]$ から評価し た $K$ は值がバラッキ，見かけ上大きな分子量依存性を 示すことも多い。以上の理由から Krigbaum 法291 の適 用はあまり妥当でない。本論文では，DMF 溶液に打け る粘度式 [(28) 式]を求めているにすぎないから，上出

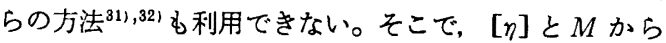
$K$ を推定する方法を採用した。

S-F プロットの適用性について検討した上出らの結 果 ${ }^{391.401}$ によると, 粘度式 [(28) 式 子量範囲において成立する場合, $0.5<a<1.0$ で，かつ 溶質の分子量が大きければ, S-Fプロット，すなわち次 式 ${ }^{31}$

$$
\frac{[\eta]}{\overline{\bar{M}}^{1 / 2}}=K+0.5 \Phi_{0} B M^{1 / 2}
$$

(ここで, $\emptyset_{0}$ は $\theta$ 溶媒における $の$ の値, $\emptyset_{0}=\emptyset\left(\alpha / \alpha_{\eta}\right)^{3}$, $B$ は長距寉相互作用（排除体積）を表わすバラメーター, $B=\beta / m_{s}{ }^{2}, \beta$ はセクメント対の binary cluster 積分, $m_{\mathrm{s}}$ は統計的セグメントの分子量）の左辺 $[\eta] / M^{1 / 2}$ を $M^{1 / 2}$ に対してブロットしても直線とはならないで, 上 に凸の曲線になる。 $a=1.0$ では S-F プロットは原点を 通る(したがって, 見かけ上 (38) 式の右辺第 1 項 $K$ は 0 となる) 直線となる。いいかえると， S-F プロットは $a=0.5$ を除いて常に真の $K$ を与えるわけではない。そ れ以外の類似の方法も S-F 法と大同小異で，本質的な 差はない37。そこで，本論文では，その適用範囲を十分 に考虑に入れて S-F プロットを行なった。

まず, PAN 溶液に対する S-Fプロットの適用限界を, 藤畸一小林 ${ }^{25}$ の実験データを利用して調べた。その結果 を Fig. 20 に示す。利用した溶媒のらち、いちばん良 溶媒である DMF 溶液についての S-F プロットは直線 とはならない。S-Fプロットの直線部分を, $\bar{M}_{w}^{1 / 2} \rightarrow 0$ で 1 点に集束するよらに外插すると， $K=2.8 \times 10^{-3}$ か 得られる。なお, 稲垣ら ${ }^{2)}$ も PAN の DMF 溶液 $\left(30^{\circ} \mathrm{C}\right)$

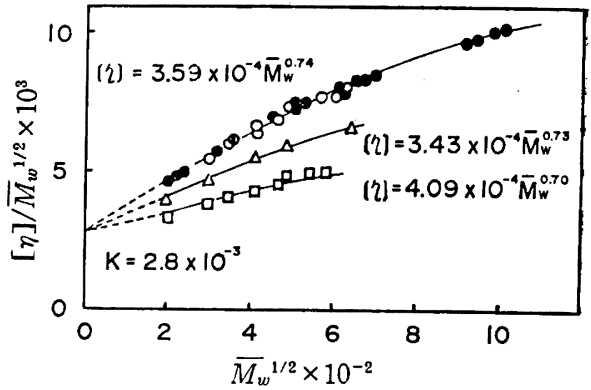

- : N, N'-dimethylformamide solution,

O: Dimethylsulfoxide solution

$\Delta: \gamma$-Butyrolacton solution,

$\square$ : Hyrroxyacetonitrile solution.

Solid curves are calculated from the MarkHouwink-Sakurada equation. Dotted lines are estimated from linear portion of the plots in lower molecular weight range. Since Stockmayer-Fixman plots do not give any straight lines, specially in the range of high molecular weight, the coincidence of the value of the intercept at $\bar{M}_{w}=0$ with Flory's $K$ value is questionable as criticized by Kamide-Moore in the case of cellulose-trinitrate. ${ }^{301,40)}$

Fig. 20. Plots of $[\eta] / \bar{M}_{w}^{\frac{1}{2}}$ versus $\bar{M}_{w}^{\frac{1}{2}}$ for poly acrylonitrile( $S-R(40)$ ) fractions in various solvents. ${ }^{11}$

のデータを S-F 法で解析し, 直線プロットから $K=2$. $05 \times 10^{-3}$ と $2.55 \times 10^{-3}$ を得た。彼らが利用した分子量 範囲は $3.8 \times 10^{4} \sim 2.95 \times 10^{5}$ 打よび $5.8 \times 10^{4} \sim 3.01$ $\times 10^{5}$ であって, 本論文のそれよりも幅が狭く，その上 低分子量側にずれている。このため，S-Fプロットが近 似的に直線となったのかもしれない。結局, PAN-DMF

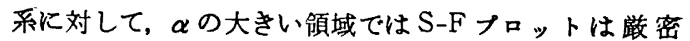
には成りたたないことが確かめられた。しかし， S-Fブ ロットを利用すると，見かけのK(したがって，見かけ の unperturbed dimension)の重合方法による変化が推 定できる。

Fig. 21 に重合条件をかえて得られた重合体の $[\eta] /$ $\bar{M}^{1 / 2}$ 対 $\bar{M}_{w}^{1 / 2}$ プロットをまとめてある。これらの重合 体の粘度式 [(28) 式 の違いからも予想されることで あるが (Fig. 14 参照)，S-Fプロットは二つの曲線と なる。 $\lim _{M^{1 / 2} \rightarrow 0}[\eta] / \bar{M}_{w}^{1 / 2}$ は,ベンゼン中の沈股重合物を除き， $3.6 \times 10^{-3}$ ，ベンゼンを溶媒とした沈殿重合物では $3.1 \times$ $10^{-3}$ となった（Table 5)。これらの値は，藤崎 - 小林 データからの値 $\left(2.8 \times 10^{-8}\right)$ や稲垣ら ${ }^{2}$ が他の報告者の 実験データをS-Fプロットして求めた值 $\left(1.98 \times 10^{-3}\right.$ 〜 $\left.2.55 \times 10^{-3}\right)$ よりもかなり大きい。利用した分子量範用 
が異なると, S-F プロットの外插值も変動することに注 意すべきである。

見かけの第 2 ビリアル係数 $A_{2}, a p$ が0 となる混 合溶 媒（エチレンカーボネート水溶液, $44^{\circ} \mathrm{C}$ ) を $\theta$ 溶媒と 近似して, 次式

$$
[\eta]_{\theta, a p}=K_{a p} \bar{M}_{w}^{1 / 2}
$$

より,レドックス重合物の $K_{a p}$ を評価すると, $K_{a p}=$ $(1.98) /\left(3.45 \times 10^{5}\right)^{1 / 2}=3.38 \times 10^{-3}$ が得られる。 $K_{a p}$ はS-Fプロットの $\lim _{M^{1 / 2} \rightarrow 0}[\eta] / \bar{M}_{w}{ }^{1 / 2}=3.6 \times 10^{-3}$ とかなり

\section{よく一致する。}

Scholtan-Marzolph ${ }^{26)}$ は $20^{\circ} \mathrm{C}$ における DMF-メタノ 一ル混合溶媒系の粘度式 [(28) 式]を，混合組成をか えて求め, $a=0.5$ を満足する DMFーメタノール (82: 18 , 容量比) 系を $\theta$ 溶媒とした。この場合, $K_{a p}=3.25$

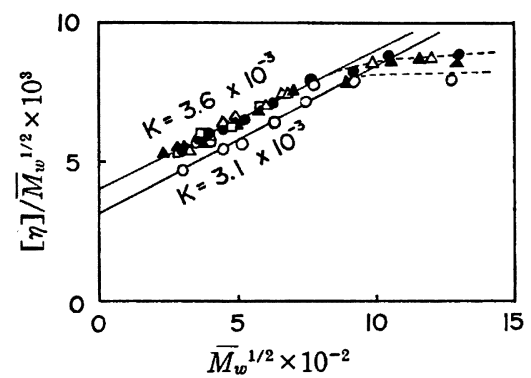

$\Delta: \mathrm{P}-n \mathrm{R}(\mathrm{B}), \square: \mathrm{P}-n \mathrm{R}(\mathrm{H}), \Delta: \mathrm{S}-\mathrm{R}(40)$,

- S-R $(-20), 0: \mathrm{S}-n \mathrm{R}$

Fig. 21. Plots of $[\eta] / \bar{M}_{w}^{\frac{1}{2}}$ against a function of $\bar{M}_{w}^{\frac{1}{2}}$ for PAN in DMF at $20^{\circ} \mathrm{C}$.

$\times 10^{-3}$ を得た。この值は, ベンゼン中沈殿重合物以外 の重合物について，本論文で得た S-F プロットからの $K お よ ひ ゙$ 見かけの $\theta$ 溶媒中の $K_{a p}$ に対してかなりよい 一致を示す。

Fig. 21 のプロットの勾配から， $0.5 \emptyset_{0} B$ 〔(38) 式参 照了が求められる。したがって, $\emptyset_{0}=2.87 \times 10^{21}$ とおけ ば，これからBを評価できる。ペンゼン中非レドックス 系沈段重合物の $B$ として, $3.7 \times 10^{-2 n}$, その他の重合物 に対して $B=3.5 \times 10^{-27}$ が得られた（Table 5)。これ より重合条件の变化は近距離作用効果により大きく影響 する。この結論は, 重心半径 $\left(\bar{S}^{2}\right)_{z}{ }^{1 / 2}$, 第 2 ビリアル係 数 $A_{2}$ や粘度式の係数 $a$ が重合条件によらない実験事実 (Fig. 15, Fig. 16, 脚注＊15) などといっけん矛盾する。 といらのは, 理論によってわずかの差はあるが, $\left(\bar{S}^{2}\right)_{z}{ }^{1 / 2}$, $A_{2}, a$ ともに unperturbed dimension $\left(\bar{r}_{0}^{2} / M\right)^{1 / 2}$ と排 除体積のBのパラメーターであるからである。たとえば, $A_{2}$ は次式 (改良 Flory-Krigbaum-Orofino 式) で与兄ら れる

$$
A_{2}=\frac{1}{2} N_{A} B \frac{\log \left(1+5.71 \frac{z}{\alpha^{3}}\right)}{5.71 \frac{z}{\alpha^{3}}}
$$

ここで, $z=0.330 B\left(\frac{\overline{r_{0}}}{M}\right)^{-3 / 2} M^{1 / 2}$

一方, Voeks"11によると $a$ は近似的に $\alpha$ の関数として 与えられる。

$$
a=\frac{4 \alpha^{2}-3}{5 \alpha^{2}-3}
$$

\begin{tabular}{|c|c|c|c|c|}
\hline Parameter & & Polymer $(\mathrm{I})^{\mathrm{a} /}$ & Polymer (II) ${ }^{\mathrm{bl}}$ & (I) $/(\mathrm{II})$ \\
\hline$K \times 10^{3}$ & $\begin{array}{l}\text { (from eq. }(38) \text { ) } \\
\text { (from eq. }(39))^{\text {c) }}\end{array}$ & $\begin{array}{l}3.6 \\
3.5\end{array}$ & 3.1 & 1.16 \\
\hline$B \times 10^{27}$ & (from eq. (38)) & 3.5 & 3.7 & 0.94 \\
\hline$\left(\bar{r}_{0}^{2} / M\right)^{\frac{1}{2}}(\AA)$ & $\left(\right.$ from $\left.K^{\mathrm{d} \prime}\right)$ & 1.08 & 1.02 & 1.06 \\
\hline$z \times 10^{4}$ & (from eq. (41)) & $9.16 \bar{M}_{w}^{0.5}$ & $11.28 \bar{M}_{w}^{0.5}$ & 0.81 \\
\hline$\alpha_{\eta} \times 10$ & (from eq. (23)) & $5.05 \bar{M}_{w}{ }^{0.07}$ & $5.16 \bar{M}_{w}^{0.07}$ & 0.98 \\
\hline \multirow[t]{3}{*}{$\alpha \times 10$} & $\left(\text { from } \alpha_{\eta}\right)^{e)}$ & $5.86 \bar{M}_{w}^{0.07}$ & $5.99 \bar{M}_{w}{ }^{0.07}$ & 0.98 \\
\hline & $\left\{\left(\operatorname{frcm} \alpha_{\eta}\right)^{p)}\right.$ & $4.27 \bar{M}_{w}^{0.09}$ & $4.41 \bar{M}_{w}{ }^{0.09}$ & 0.97 \\
\hline & (from eq. (24)) & $7.06 \bar{M}_{w}{ }^{0.12}$ & $7.48 \bar{M}_{w}^{0.12}$ & 0.98 \\
\hline
\end{tabular}
本論文で得た $[\eta],\left(\bar{r}_{0}^{2} / M\right)^{3 / 2}$ および $B$ を (23) 式, PNA - DMF system at $20^{\circ} \mathrm{C}$.

a) Polymer prepared by the radical polymerization with non-redox initiator in benzene $\mathrm{P}-n \mathrm{R}(\mathrm{B})$

b) Polymer pre pared by the radical polymerization except Polymer (I)

c) Ethylene carbonate-water ( $85: 15$ in weight) system at $44^{\circ} \mathrm{C}$ was determined from the light scattering measurement as apparent $\theta$ solvent for PAN of type (I), in which apparent second virial coefficient becomes zero (see text)

d) $\left(\bar{r}^{2} / M\right)^{\frac{1}{2}}=\left(K / \Phi_{0}\right)^{1 / 3}$, where, $\emptyset_{0}=2.87 \times 10^{21}$

e) $\alpha=1.16 \alpha_{\eta}$, f) $\alpha=\alpha_{\eta}^{3 / 2 \cdot 43}$ 
(40) 式〜 (42) 式に代入すると (Table 5 参照), $A_{2}$ とa が計算できる。 $A_{2}$ の計算值は実測值よりる小さくなる。 これは（40）式を導く際に用いた理論の近似のあらさの ためである。しかし，今，問題としている $A_{2}$ の相対的変化 を調べるたけけは十分利用できる。（42）式から求めた $a$ は実測値とかなり良く一致した。非レドックス系沈殿重 合物の $\left(\bar{S}_{2}{ }^{2}\right)_{2}^{1 / 2}, A_{2}, a$ いずれも計算値は他の重合物の それよりもわずか大きい。しかし，重合条件による差は きわめてわずかで, $\left(\bar{S}^{2}\right)_{2}^{1 / 2}$ について約 $2 \%, A_{2}$ に関し て1〜2\%,aについては1〜3\%にすぎない。結局, 実験的には，粘度式に差があっても， $\left(\bar{S}^{2}\right)_{z}^{1 / 2}, A_{2}, a$ に は差が認められないのは相互に矛盾しないといえる。

\section{3 ベンゼン中沈殿重合物の溶液物性の特異性}

ベンゼンを溶媒とした沈殿重合物 $(\mathrm{P}-n \mathrm{R}(\mathrm{B}))$ の溶夜 物性は，次のような特異性をむつ。

1）いちばん強い螢光を発する。また，見かけの散乱 光の偏光解消度も大きい (2.4.2)。

2) 屈折率の濃度変化 $\partial n / \partial c$ が大り (2.4.1)。

3）低分子量側では, Huggins 係数 $k_{1}$ は分子量の 增加につれて減少する (3.1)。

4）同一 $\bar{M}_{w}$ をるつ他重合法の重合物の $[\eta]$ よりも 約 $10 \%$ 小さい $[\eta]$ をむつ (3.2)。

5）他重合物より unperturbed dimension は小さく, 排除体積効果は大差ない(4.2)。

これらの特異性の原因を以下, 二三検討した。なお $\partial n / \partial c$ が大きければ [2)], 得られる分子量はより小 さくなる。だから, 同一 $[\eta] て ゙$ 比較すると, $(\mathrm{P}-n \mathrm{R}(\mathrm{B}))$ 重合物の $\bar{M}_{w}$ が大きくなる[4)] のは, $\partial n / \partial c$ の值の
相连 [2)〕々直接関係ない。n-ヘブタン中で沈殿重含 させて得た重合物の $\partial n / \partial c$ むきい(Fig. 2) にもか かわらず, 粘度式に異常はない。

\section{3 .1 分岐構造}

(P-nR(B)) 重合物が分岐構造をもつ可能性について 溶液物性的に検討した。結果を Table 6 にまとめてあ る。溶液物性の特異性は, 分岐構造の存在を仮定して も, 説明できない。著者らの知るかぎりでは, PAN分 子に分岐が存在することはまだ直接実験的には証明され ていない。

\section{3.2 立体規則性度の違い}

一般に, 良溶媒中においては， $A_{2}$ は試料の立体規則 性度の影響を受けるのに反し，Mark-Houwink-桜田式 は立体規則性度にほとんど無関係であることが広く知ら れている42)。本論文で用いた試料のミクロタクチシテ1 は, 重合条件によって変化せずほぼ一定である(2.3.1 参照)*16。一方, 粘度式の係数 $a(0.71), A_{2}$, 捄よ $z$ などから判断すると, DMFは PAN に対してかなりの 良溶媒である。PAN-DMF 系における $A_{2}$ の分子量依 存性は重合法によらない。以上の実験事実より, 粘度式 〔(28)式〕が重合方法によって異なることを，立体規則 性度の変化に原因づける積極的根処は見出せない。立体 規則生度のわずかの变化か，良溶媒中の粘度式を変化さ せると仮定するのは困難である。

\section{3.3 異種構造}

4.3.1，4.3.2 から明らかなよらに, 分岐構造や立体 規則性度が違ら可能性は否定された。

$(\mathrm{P}-n \mathrm{R}(\mathrm{B}))$ 重合物は強い䝁光を発し, その螢光は非 イオン型である (4.1)。一般に, 螢光の原因はPAN 分

Table 6. Possibility of branching in $\mathrm{P}-n \mathrm{R}(\mathrm{B})$ polymer fractions.

\begin{tabular}{l|c|c|c}
\hline \multicolumn{1}{c|}{ Parameter } & $\begin{array}{c}\text { Theoretical } \\
\text { prediction }^{\mathrm{a})}\end{array}$ & Experimental result & $\begin{array}{l}\text { Coincidence of experimental } \\
\text { result with theoretical pre- } \\
\text { diction }\end{array}$ \\
\hline$[\eta]_{I} /[\eta]_{I I}\left(\equiv g_{\eta}{ }^{3}\right)$ & $<1.0$ & 0.93 & 0 \\
$\left(\bar{S}^{2}\right)_{I} /\left(\bar{S}^{2}\right)_{I I}\left(\equiv g_{s}{ }^{2}\right)$ & $<1.0$ & ca. 1.0 & $\times$ \\
$g_{\eta} / g_{S}$ & $>1.0$ & $<1.0$ & $\times$ \\
$a_{I} / a_{I I}$ & $<1.0$ & 1.0 & $\times$ \\
$\left(A_{2}\right)_{I} /\left(A_{2}\right)_{I I}$ & $<1.0$ & ca. 1.0 & $\times$ \\
$\left(A_{2} M /[\eta]\right)_{I} /\left(A_{2} M /[\eta]\right)_{I I}$ & $<1.0$ & $>1.0$ & $\times$ \\
\hline
\end{tabular}

a) If it is assumed that polymers I and II correspond to branching and linear polymers, respectively. Polymer I: Polymers prepared by the radical polymerization with non-redox initiater in benzene. Polymer II: Polymers prepared by the radical polymerization except
polymer 1 .

\footnotetext{
*16 NMR スペクトルを解析して得られるミクロタクチシ ティは全試料を通じて一定であっても，より長距難に わたる立体规則性度（タクチシティ）は試料によって 異なる可能性がある。この場合でも, むしろ低温レド ックス重合物のタクチシティが異なるはずである。
} 
子中の異種構造であるが, $(\mathrm{P}-n \mathrm{R}(\mathrm{B}))$ 重合物の螢光構 造はベンゼン環を含むと推論されたが，まだ同定されて いない（4.1)。一方，カルボニル基をいちばん多く含む 非レドックス系水中けん濁重合物やレドックス系けん濁 重合物は正常な溶液物性をもつ。したがって，分子鎖中 に異種構造をもてば溶液物性が特異的になるわけでは決 してない。このうち，分子鎖末端にベンゼン環を含む異 種構造が溶液物性の異常性の原因と考えられる。これを 確認するためには, 今後のより系統的な研究が必要であ る。

\section{5. 結 論}

ラジカル重合物の立体規則性度は重合条件を変えても 変化しない。その溶液物性は重合 温度の影響を受けな い。ペンゼンを溶媒とした非レドックス系沈䟝重合物は ゆちばん強い螢光をもち，屈折率の濃度依存性が大き く, 低分子量領域では Huggins 係数 $k_{1}$ が大きく，同 一分子量の他の重合物よりも $10 \%$ 小さい $[\eta]$ をむつ。 この原因は, 分子鎖の比較的末端に存在するベンゼン環 を含さ異種結合と推定される。

付 記：本論文の発表を許可された旭化成工業株式 会社に感謝する。本研究の実施にあたり実験の一部を 補助された旭化成工業株式会社瀻維研究所真田昌彦氏, 高分解能核磁気共鳴吸収を測定された当社技術研究所 解析研究室長南雲 正博士, 本論文の 2.4.2 に関して 有意義な討論をして下さった京都大学化学研究所内山 敬康博士にお礼申上げる。

\section{文献}

1）藤崎誼達，小林秀彦：高化, 19, 73 (1962)

2) H. Inagaki, K. Hayashi, T. Matsuo : Makromol. Chem., 84, 80 (1965)

3) W.H. Stockmayer, M. Fixman : J. Polymer Sci., C-1, 137 (1963)

4）村野政生, 山寺礼三：高化，23，497（1966）

5) K. Matsuzaki, T. Uryu, K. Ishigure, M. Takeuchi : J. Polymer Sci., B4. 93 (1966)

6) 藤崎誼達：高化，18，581 (1961)

7）藤崎誼達，小林秀彦：高化, 19, 49 (1962)

8) W.R. Krigbaum, A.M. Kotliar: J. Polymer Sci., 32, 323 (1958)

9) R.L. Cleland, W.H. Stockmayer : J. Polymer Sci. 17, 473 (1955)

10) B.A. Brice, G.C. Natting, M.A. Halwer : J. Am. Chem. Soc., 75, 824 (1952)

11）たとえば, 小泉正夫：光化学概論, 朝會書店 (1 963)
12）たとえば, 中垣正幸, 稲垣 博編：光散乱実験法, 第 6 章, 南江堂 (1965)

13) H. Utiyama : J. Phys. Chem., 69, 4138 (1965)

14) H. Utiyama, M. Kurata: Bull. Inst. Chem. Res.Kyoto Univ., 43, 128 (1964)

15) 内山敬康： 京都大学 学位論文 (1962)

16）たとえば, M.V. Volkonstein： Chap. 7 “Con. figurational Statistics of Polymeric Chains" Interscience Pub. Co. (1963)

17) H. Kobayashi : J. Polymer Sci. B1, 299 (1963)

18) L.H. Peebles, Jr: J. Am. Chem. Soc., 80, 5603 (1958)

19) R.C. Houtz: Text. Res. J., 20, 786 (1950)

20) H. Frind: Faserforschung und Textiltechnik, 5, 540 (1954)

21) J. Bisschops: J. Polymer Sci., 17, 81 (1955)

22) G. Ciampa, H. Schwindt: Chim. e Ind. (Milan) 37, 169 (1955)

23) P.F. Onyon: J. Polymer Sci., 22, 13 (1956)

24) H. Kobayashi : J. Polymer Sci., 39, 369 (1959)

25）藤崎誼達，小林秀彦：高化，19,81（1962）

26) W. Scholtan, H. Marzolph : Makromol. Chem., 57, 52 (1962)

27) S.K. Das, S.R. Chatterjee, S.R. Palit : Proc. Roy. Soc., A227, 252 (1955)

28) W.R. Krigbaum : J. Polymer Sci., 28, 213 (1958)

29）上出健二, 河合 徹 : 高化，20，506（1963）

30) M. Kurata. M. Fukatsu, H. Sotobayashi, H. Yamakawa: J. Chem. Phys., 41, 139 (1964)

31）上出健二, 河合 徽：高化, 20, 512 (1963)

32）上出健二, W.R. Moore：高化, 21, 682 (1964)

33) P.J. Flory, T.G. Fox : J. Am. Chem. Soc., 73, 1904 (1951)

34) M. Kurata, W.H. Stockmayer : Fortsch. Hochpolym. Forsch., 3, 196 (1963)

35) H. Inagaki, H. Suzuki, M. Kurata : J. Polymer Sci., C-15, 409 (1966)

36) M. Bohdanecky : J. Polymer Sci., B3, 201 (1965)

37) J.M.G. Cowie : Polymer, 7, 487 (1966)

38) C.F. Cornet: Polymer, 6, 373 (1965)

39）上出健二, W.R. Moore : 高化, 21, 694 (1964)

40) K. Kamide, W.R. Moore: J. Polymer Sci, B2, 1029 (1964)

41) J.E. Voeks : J. Polymer Sci., 36, 333 (1959)

42）たとえば，上出健二：高分子，11，49 (1963), 中島章夫：高分子の物性（I ），化学同人（1963） 


\title{
Influence of the Polymerization Conditions on the Dilute Solution Properties of Polyacrylonitrile.
}

\author{
By Kenji Kamide*, Hidehiko Kobayashi**, Yukio Miyazaki** and Chozo Nakayama***
}

The light scattering and viscosity measurements were carried out on fractions in $\mathrm{N}, \mathrm{N}^{\prime}$ dimethylformamide at $20^{\circ} \mathrm{C}$. The fractions chosen for this study were polymers prepared by suspension $(S)$ or precipitation $(P)$ polymerization in aqueous or organic (benzene (B) or $n$-heptane $(\mathrm{H})$ ) system with redox $(\mathrm{R})$ or non-redox $(n \mathrm{R})$ catalyst as initiator. Fractions were, in advance, characterized by high resolution nuclear magnetic resonance and infra-red spectra, leading to the conclusion that the degree of microtacticity of polymeric chains is almost constant independent of molecular weight and polymerization conditions. The larger values of refractive increment than those in literatures were obtained for $(\mathrm{P}-n \mathrm{R})$ polymer. For fractions polymerized in benzene, the fluorescence had a large effect on the Zimm plot giving the slope with minus sign for $c=0$ line in the range of small angle of scattering, even if $546 \mathrm{~m} \mu$ as incident light was used. The optical anisotropy of the chain effected little on this kind of distortion appearing in the Zimm plot. Apparent depolarization, of which the magnitude remarkably depended on the conditions of polymerization, decreased with increase of molecular weight. After corrections of fluoresoence, $0.01 \sim 0.02$ as depolarization factor of scattered light was obtained irrespective of the molecular weight and the preparative procedure.

Relationships between the intrinsic viscosity and molecular weight were determined for polymers except $(\mathrm{P}-n \mathrm{R}(\mathrm{B})):[\eta](\mathrm{d} l / \mathrm{g})=4.66 \times 10^{-4} \bar{M}_{w}{ }^{0.71}$ and for $(\mathrm{P}-n \mathrm{R}(\mathrm{B}))$ polymer : $[\eta]$ $(\mathrm{d} l / \mathrm{g})=4.29 \times 10^{-4} \bar{M}_{w}{ }^{0.71}$. On the other hand, the identical relationships were obtained between the radius of gyration $\left(\bar{S}^{2}\right)_{z}^{\frac{1}{2}}$ or second virial coefficient $A_{2}$ and molecular weight irrespective of the polymerization conditions: $\left(\bar{S}^{2}\right)_{2}^{\frac{1}{2}}(\mathrm{~cm})=1.27 \times 10^{-9} \bar{M}_{w}{ }^{0.62}$ and $A_{2}\left(\mathrm{ml} / \mathrm{g}^{2}\right)$ $=4.94 \times 10^{-2} \bar{M}_{w}{ }^{-0.27}$. The correlationships among the parameters in the above equations were discussed in detail.

Applicability of the Stockmayer-Fixman plot was examined. Flory constant $K=3.1 \times 10^{-s}$ for $(\mathrm{P}-n \mathrm{R}(\mathrm{B}))$ polymer and $3.6 \times 10^{-8}$ for other polymers were determined by extrapolating the linear portion of the plot to $\bar{M}_{w}{ }^{\frac{1}{2}}=0$. From viscosity measurements on the redox polymer in ethylene carbonate-water ( $85: 15$, in weight) system at $44^{\circ} \mathrm{C}$ for which $A_{2}$ vanishes, $K=3.5 \times 10^{-3}$ was estimated. The experimental results that the polymerization conditions influenced only the parameter $K_{m}$ in the Mark-Houwink-Sakurada equation $[\eta]=K_{m}$ $\bar{M}_{w}{ }^{a}$, but not on $a$ and molecular weight dependence fo $\left(\bar{S}^{2}\right)^{\frac{1}{2}}$ or $A_{2}$ were resonably interpreted by the recent solution theories.

Fluorescence appearing in dimethylformamide solution did not depend on the content in amide, carboxylic acid and it's ester existing in polymer as aknormal structures. Fluorescence of the redox polymer was of ionic and that of $(P-n R(B))$ polymer was of non-ionic type.

\footnotetext{
* Textile Research Laboratory, Asahi Chemical Industry Co. Ltd. (Ama, Takatsuki, Osaka)

** Technical Research Laboratory, Asahi Chemical Industry Co. Ltd. (Shimura, Itabashi-ku, Tokyo)

*** Fibers Planning Department, Asahi Chemical Industry Co. Ltd. (Dozima, Kita-ku, Osaka)
} 